\title{
Interactions between Vegetation and Climate: Radiative and Physiological Effects of Doubled Atmospheric $\mathrm{CO}_{2}$
}

\author{
L. Bounoua, * G. J. Collatz, ${ }^{+}$P. J. Sellers,\# D. A. Randall, ${ }^{@}$ D. A. Dazlich, ${ }^{@}$ S. O. Los, \& \\ J. A. Berry, ** I. Fung, ${ }^{+}+$C. J. Tucker, ${ }^{+}$C. B. Field, ${ }^{* *}$ And T. G. Jensen $@$ \\ * Department of Meteorology, University of Maryland, College Park, Maryland, and NASA/GSFC, \\ Biospheric Sciences Branch, Greenbelt, Maryland \\ + NASA/GSFC, Biospheric Sciences Branch, Greenbelt, Maryland \\ \# NASA/JSC, Houston, Texas \\ @ Department of Atmospheric Sciences, Colorado State University, Fort Collins, Colorado \\ $\&$ Science Systems and Applications, Inc., NASA/GSFC, Biospheric Sciences Branch, Greenbelt, Maryland \\ ** Department of Plant Biology, Carnegie Institution of Washington, Stanford, California \\ ++ Department of Earth and Ocean Sciences, University of Victoria, Victoria, British Columbia, Canada
}

(Manuscript received 7 August 1997, in final form 21 January 1998)

\section{ABSTRACT}

\begin{abstract}
The radiative and physiological effects of doubled atmospheric carbon dioxide $\left(\mathrm{CO}_{2}\right)$ on climate are investigated using a coupled biosphere-atmosphere model. Five 30-yr climate simulations, designed to assess the radiative and physiological effects of doubled $\mathrm{CO}_{2}$, were compared to a 30-yr control run.

When the $\mathrm{CO}_{2}$ concentration was doubled for the vegetation physiological calculations only assuming no changes in vegetation biochemistry, the mean temperature increase over land was rather small $(0.3 \mathrm{~K})$ and was associated with a slight decrease in precipitation $(-0.3 \%)$. In a second case, the vegetation was assumed to have adapted its biochemistry to a doubled $\mathrm{CO}_{2}\left(2 \times \mathrm{CO}_{2}\right)$ atmosphere and this down regulation caused a $35 \%$ decrease in stomatal conductance and a $0.7-\mathrm{K}$ increase in land surface temperature. The response of the terrestrial biosphere to radiative forcing alone - that is, a conventional greenhouse warming effect-revealed important interactions between the climate and the vegetation. Although the global mean photosynthesis exhibited no change, a slight stimulation was observed in the tropical regions, whereas in the northern latitudes photosynthesis and canopy conductance decreased as a result of high temperature stress during the growing season. This was associated with a temperature increase of more than $2 \mathrm{~K}$ greater in the northern latitudes than in the Tropics $(4.0 \mathrm{~K}$ vs $1.7 \mathrm{~K})$. These interactions also resulted in an asymmetry in the diurnal temperature cycle, especially in the Tropics where the nighttime temperature increase due to radiative forcing was about twice that of the daytime, an effect not discernible in the daily mean temperatures. The radiative forcing resulted in a mean temperature increase over land of $2.6 \mathrm{~K}$ and $7 \%$ increase in precipitation with the least effect in the Tropics. As the physiological effects were imposed along with the radiative effects, the overall temperature increase over land was $2.7 \mathrm{~K}$ but with a smaller difference $(0.7 \mathrm{~K})$ between the northern latitudes and the Tropics. The radiative forcing resulted in an increase in available energy at the earth's surface and, in the absence of physiological effects, the evapotranspiration increased. However, changes in the physiological control of evapotranspiration due to increased $\mathrm{CO}_{2}$ largely compensated for the radiative effects and reduced the evapotranspiration approximately to its control value.
\end{abstract}

\section{Introduction}

There is good evidence that human activity has resulted in the increase in the atmospheric content of many so-called greenhouse gases (e.g., Boden et al. 1994), which are capable of absorbing longwave radiation from the earth's surface, causing warming of the lower atmosphere. Among long-lasting anthropogenic greenhouse gases, carbon dioxide is expected to have the largest direct effect on the earth-atmosphere radiative

Corresponding author address: Dr. Lahouari Bounoua, NASA/ GSFC, Code 923, Greenbelt, MD 20771.

E-mail: bounoua@dounia.gsfc.nasa.gov balance. The atmospheric carbon dioxide $\left(\mathrm{CO}_{2}\right)$ concentration has increased from about $280 \mathrm{ppm}$ in preindustrial times to the current level of about $350 \mathrm{ppm}$ and is increasing at the rate of about $1.5{\mathrm{ppm} \mathrm{yr}^{-1}}^{-1}$ (Houghton et al. 1996).

During the last decade, $\mathrm{CO}_{2}$-induced climate change has been a subject of interest for many climate modelers (e.g., Bryan and Spelman 1985; Washington and Meehl 1989; Stouffer et al. 1989; Murphy 1995; Murphy and Mitchell 1995). A recent assessment of the responses generated by different general circulation models to an increase in atmospheric $\mathrm{CO}_{2}$ shows that the global surface air temperature average could increase by $1.5^{\circ}-$ $4.5^{\circ} \mathrm{C}$ (Houghton et al. 1990; Houghton et al. 1996). In all these studies, however, the impacts of increasing $\mathrm{CO}_{2}$ 
were associated only with changes in radiative properties of the atmosphere; the potential interactions between $\mathrm{CO}_{2}$, vegetation, and climate were not considered. GCM sensitivity studies that have focused on the impact of vegetation on climate [i.e., Amazon deforestation (Nobre et al. 1991) and boreal deforestation (Bonan et al. 1992)] have shown that significant feedback on simulated climate can occur due to altering the vegetation characteristics. It is therefore plausible that vegetation responses to elevated atmospheric $\mathrm{CO}_{2}$, if strong enough, may significantly influence the overall climate system response. Recently, Henderson-Sellers et al. (1995) imposed a global doubling of the canopy resistance to water vapor flux in order to approximate the physiological response of vegetation to doubled atmospheric $\mathrm{CO}_{2}$ and found greater warming than when radiative forcing alone was imposed. To understand how $\mathrm{CO}_{2}$ might affect land surface-climate interactions, it is necessary to consider how vegetation might respond to $\mathrm{CO}_{2}$ directly and how this response may influence the water and energy balance of vegetated land surfaces.

Leaves of terrestrial vegetation take up $\mathrm{CO}_{2}$ from the atmosphere as a part of photosynthesis. As $\mathrm{CO}_{2}$ diffuses into the leaf, water vapor from the leaf is lost to the atmosphere through transpiration. Plants control the diffusion of $\mathrm{CO}_{2}$ and water vapor by adjusting the size of small openings in the leaf surface called stomata. Stomata seem to adjust in response to environmental and physiological conditions in a manner that maximizes the amount of carbon gained for a given rate to transpiration (Cowan 1977). Thus, leaf stomatal conductance to water vapor diffusion appears to be sensitive to variations in the net carbon assimilation rate, which in turn depends on light intensity, air temperature, soil-water content, and atmospheric $\mathrm{CO}_{2}$ concentration, as well as on changes in humidity. Leaf-scale models of net photosynthetic assimilation and stomatal conductance have been formulated to describe these relations (e.g., Cowan and Farquhar 1977; Collatz et al. 1991; Collatz et al. 1992).

The physiological responses to increased atmospheric $\mathrm{CO}_{2}$ concentration that have potential consequences for climate result mainly from the dependence of photosynthesis and stomatal conductance on $\mathrm{CO}_{2}$ partial pressure as shown by the theoretical models (Collatz et al. 1991; Collatz et al. 1992) in Fig. 1. Two different photosynthetic physiologies are considered here, $\mathrm{C} 3$ and $\mathrm{C} 4$. The C3 type occurs in most woody plants and temperate herbaceous plants and the C4 type is dominant in tropical and subtropical herbaceous vegetation such as savannas. These two types are distinguished by their different responses to temperature and $\mathrm{CO}_{2}$ partial pressure (Fig. 1a). Short-term exposure of C3 plants to a doubling of $\mathrm{CO}_{2}$ concentration stimulates photosynthesis (Figs. 1a,b) and decreases the stomatal conductance (Fig. 1c) from $\mathrm{C}$ [control $\left.\left(1 \times \mathrm{CO}_{2}\right)\right]$ to $\mathrm{P}$ [physiological response to $\mathrm{CO}_{2}$ doubling $\left.\left(2 \times \mathrm{CO}_{2}\right)\right]$. After a long-term exposure to increased $\mathrm{CO}_{2}$ concentration, some plants have been
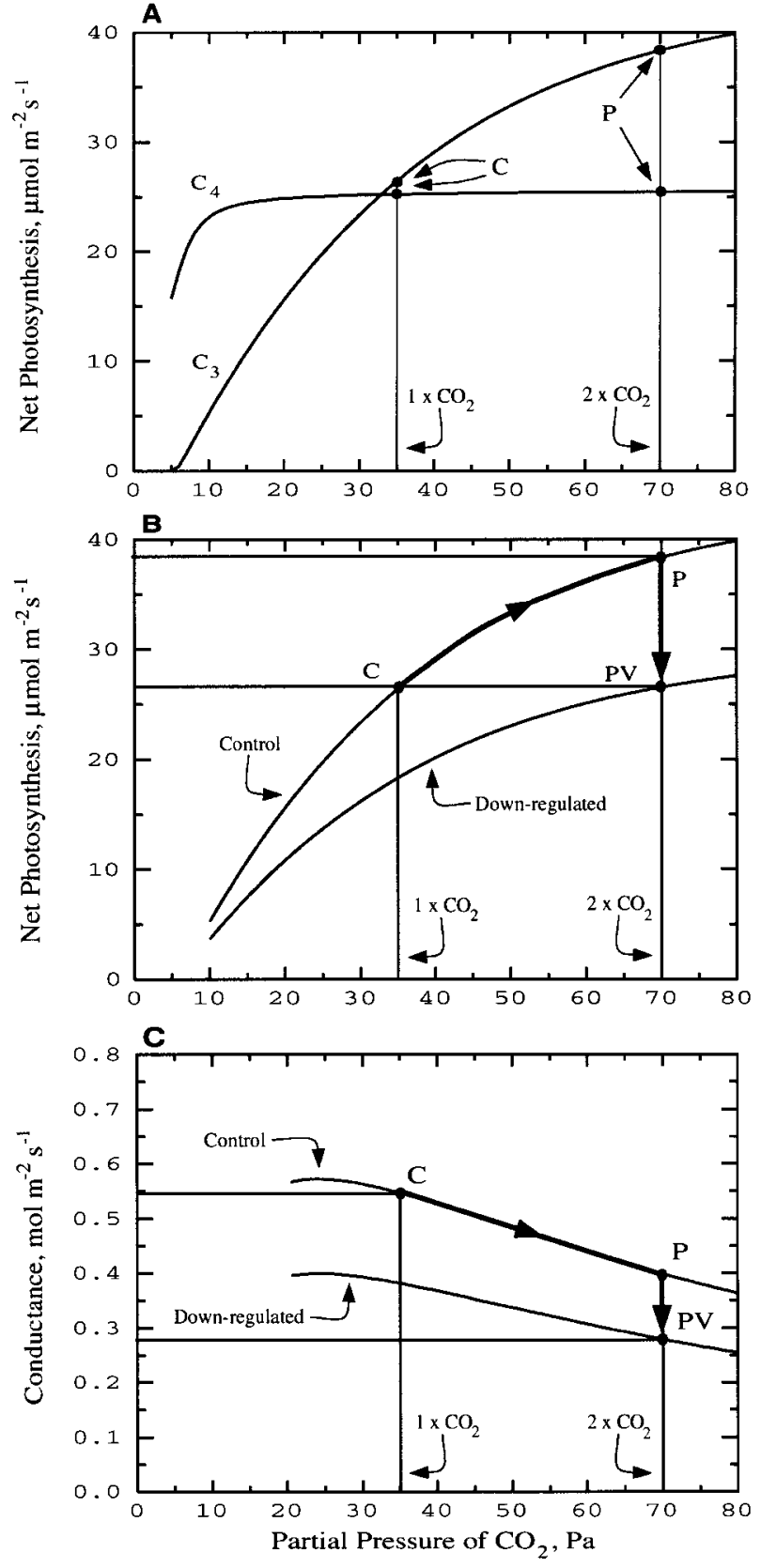

FIG. 1. Leaf photosynthesis and conductance response to atmospheric $\mathrm{CO}_{2}$ concentration for light-saturated conditions based on leaf-scale model and including a constant leaf boundary layer. (a) Dependence of leaf-scale photosynthesis for $\mathrm{C}_{3}$ and $\mathrm{C}_{4}$ vegetation on external $\mathrm{CO}_{2}$ concentration. (b) The $\mathrm{C} 3$ photosynthesis curves for unadjusted ( $\mathrm{C}$ and $\mathrm{P}$ ) and down-regulated (PV) physiology. (c) Dependence of stomatal conductance on $\mathrm{CO}_{2}$ concentration for the unadjusted and down-regulated cases.

observed to reduce their maximum photosynthesis capacity to maintain about the same rate of photosynthesis as under normal $\left(1 \times \mathrm{CO}_{2}\right)$ conditions (see Field et al. 1992; Tissue et al. 1993). The extent of this "down regulation" of physiological capacity depends on spe- 
cies, nutrient availability, and environmental stress (Field et al. 1991; Gunderson and Wullschleger 1994). The modeled response of photosynthesis for the case of down regulation at $2 \times \mathrm{CO}_{2}$ is indicated by PV in Figs. $1 \mathrm{~b}, \mathrm{c}$. These calculations, made at constant temperature, high shortwave radiation, and unstressed conditions, show that doubling $\mathrm{CO}_{2}$ causes reductions in stomatal conductance of about $25 \%$ in the $\mathrm{P}$ case, and $50 \%$ in the PV case, which are within the range observed for trees and herbaceous species (Morison 1987; Field et al. 1995). Analyses of stomatal densities in fossilized or otherwise preserved leaf surfaces have shown that leaf stomatal conductance is negatively correlated with past changes in atmospheric $\mathrm{CO}_{2}$ concentration (Woodward 1987; Penuelas and Matamala 1990; Beerling and Woodward 1996). The line segments linking the $P$ and PV points in Figs. 1b,c thus describe the likely range of leaf-scale physiological responses to doubling of atmospheric $\mathrm{CO}_{2}$ concentration in the absence of other climate effects. Photosynthesis could increase significantly, with an associated small reduction in stomatal conductance ( $\mathrm{P}$ case), or it might remain more or less constant with a larger reduction in stomatal conductance and consequently transpiration (PV case). The actual responses probably lie between these two cases.

In this paper we use a physiological model coupled to a global land-ocean-atmosphere model to investigate the potential for additional warming over the continents resulting from the physiological response of vegetation to an equilibrium doubling of atmospheric $\mathrm{CO}_{2}$ concentration and to assess its effect on climate. Results from this study were summarized by Sellers et al. (1996a).

\section{Model description and experimental design}

\section{a. The coupled model}

This investigation was carried out using the Colorado State University General Circulation Model (CSU GCM; Randall et al. 1996) coupled to the improved Simple Biosphere Land Surface Model (SiB2; Sellers et al. 1996b). The CSU GCM uses the solar and terrestrial radiation parameterization (Harshvardhan et al. 1987), which includes the heating effects due to water vapor, carbon dioxide, and ozone. The solar radiation description includes Rayleigh scattering as well as absorption by water vapor and ozone, and it simulates both the diurnal and seasonal cycles. The radiative transfer calculations are performed every hour. The model uses an improved Arakawa-Schubert cumulus parameterization scheme as discussed by Randall and Pan (1993) and includes a detailed cloud microphysics parameterization (Fowler et al. 1996; Fowler and Randall 1996a,b).

The governing equations are solved using finite differences with highly conservative schemes (Arakawa and Lamb 1977, 1981). The vertical discretization of the GCM is based on a modified sigma coordinate in which the planetary boundary layer top is a coordinate surface, so that the boundary layer is identified with the lowest model level (Suarez et al. 1983). The CSU GCM also incorporates a simple "slab" upper-ocean model, using a flux adjustment technique, and a sea-ice model (Jensen et al. 1995; Hansen et al. 1984, 1988). A more detailed description of the CSU GCM is given in Randall et al. (1996).

$\mathrm{SiB} 2$ incorporates a coupled photosynthesis-conductance parameterization to describe the simultaneous transfers of $\mathrm{CO}_{2}$ and water vapor in and out of the leaf, respectively (Collatz et al. 1991; Collatz et al. 1992; Sellers et al. 1992; Sellers et al. 1996b). Stomatal conductance $(g)$ controls the transpiration flux and the $\mathrm{CO}_{2}$ flux between the leaf and the atmosphere. It is expressed in the model as a function of the photosynthesis rate $(A)$, leaf surface relative humidity $\left(h_{s}\right)$, and $\mathrm{CO}_{2}$ partial pressure $\left(C_{s}\right)$ as

$$
g=m A h_{s} C_{s}^{-1}+b,
$$

where $m$ and $b$ are treated as vegetation-dependent parameters that set the sensitivity of leaf conductance to physiological and environmental conditions and minimum conductance, respectively. Equation (1) is scaled from individual leaf to grid cell canopy according to Sellers et al. (1992).

SiB2 has 11 prognostic state variables: three temperatures describing the canopy, the ground surface, and the deep soil; two water stores and two snow/ice stores, representing the interception by the canopy and the soil surface; three soil moisture stores; and a prognostic stomatal conductance. The canopy evapotranspiration has two components: the evaporation of snow/ice or water intercepted by the canopy and the transpiration of soil water extracted from the root zone and lost to the atmosphere from dry leaf surfaces. Similarly, evaporation from the soil consists of a loss from snow/ice and water held on the ground surface and evaporation of water from the top soil layer. A parameterization of subgridscale canopy and soil interception of convective precipitation is used to produce a more realistic partitioning of energy among the latent heat flux components. The fluxes of heat, water, and $\mathrm{CO}_{2}$ are described in terms of electrical analogs (Sellers et al. 1996b) with three potential differences expressed as temperatures, vapor pressures, and $\mathrm{CO}_{2}$ partial pressures, respectively. The resistances are equivalent to the inverse conductances integrated over the path of the potential difference endpoints.

SiB2 recognizes 12 vegetation classes as described in Sellers et al. (1996c). Satellite remote sensing data are used to prescribe the vegetation type and phenology. Monthly fields of the fraction of photosynthetically active radiation absorbed by the canopy (FPAR), the total leaf area index (LAI), and the canopy greeness fraction are derived from specially processed Advanced Very High Resolution Radiometer data (Sellers et al. 1996c). 


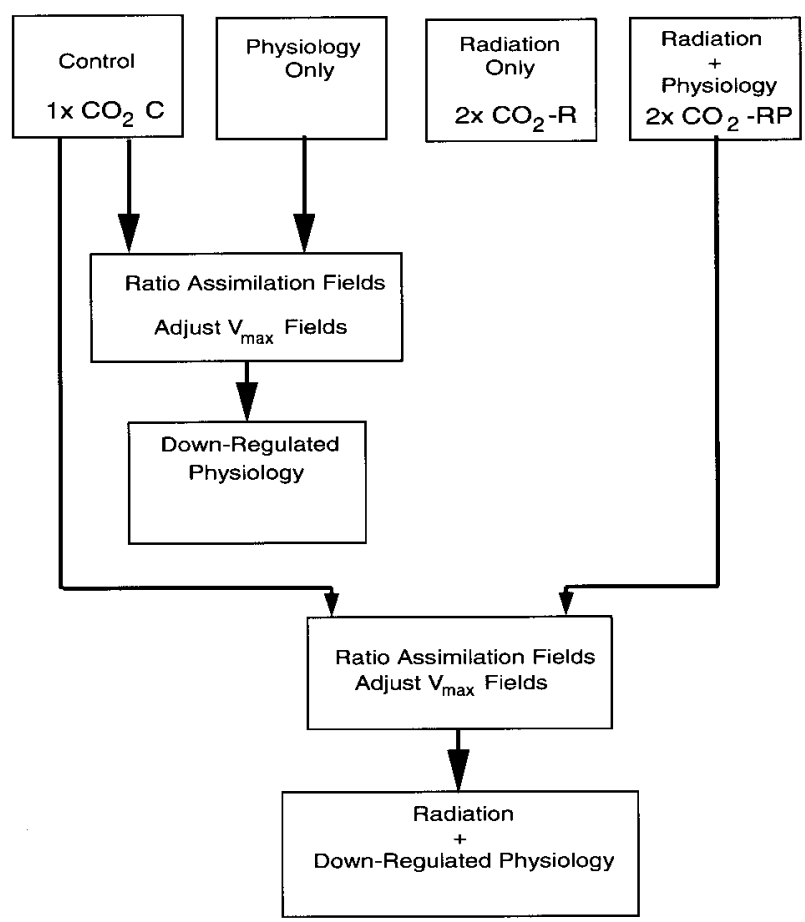

FIG. 2. Sequence and type of numerical simulations performed with the biosphere-atmosphere-ocean model (see text for details).

FPAR is used in the photosynthesis-conductance model to scale the stomatal conductance and the leaf photosynthesis to the canopy level, and the LAI is used in the turbulent and radiative transfer calculations.

The incorporation of a realistic canopy photosynthesis-conductance model and the use of satellite data make this global climate model unique among those used to simulate the effects of increased atmospheric $\mathrm{CO}_{2}$ concentration on the physical climate. The coupled SiB2GCM produces plausible fields of evapotranspiration, carbon assimilation, and the components of the surface energy balance, in addition to realistic climate simulations. Randall et al. (1996) showed that the coupled SiB2-GCM, tested in multidecade simulations, produced results that are in fair agreement with observations. In addition to improving the simulation of the surface air temperature and the hydrological cycle, the introduction of $\mathrm{SiB} 2$ in the CSU GCM has also allowed quantification of the rate of carbon assimilation by the land surface vegetation. Results from simulations produced by this coupled global climate model have been used in other biosphere-atmosphere studies (e.g., Ciais et al. 1995a; Denning et al. 1995; Ciais et al. 1995b; Denning et al. 1996a,b).

\section{b. The experimental design}

Six long-term equilibrium climate simulations were performed with the coupled SiB2-GCM (Fig. 2). The runs were conducted at $7.2^{\circ}$ lat $\times 9.0^{\circ}$ long horizontal resolution with nine layers. Because these runs were performed at rather low resolution, the simulated climate is less realistic than that obtained in runs of the same model at higher resolution (Randall et al. 1996). Implied ocean heat tranports (Hansen et al. 1984; Jensen et al. 1995) and initial conditions were obtained from a preliminary $10-y r$ run driven by observed climatological sea surface temperatures and current atmospheric $\mathrm{CO}_{2}$ concentration. This was followed by the six $30-\mathrm{yr}$ simulations in which sea surface temperature and sea ice were allowed to evolve with time.

1) The first run is the control (C) simulation. The coupled model was integrated for $30 \mathrm{yr}$ using the current atmospheric $\mathrm{CO}_{2}$ concentration for both the radiative transfers code in the GCM and the vegetation model.

2) The second simulation was aimed at evaluating the physiological response to doubled $\mathrm{CO}_{2}$ and its impact on climate. This "physiology-only" (P) run consisted of operating the radiative transfers under $1 \times \mathrm{CO}_{2}$ whereas the $\mathrm{CO}_{2}$ concentration in the physiological model was instantaneously doubled to 700 ppm, thus directly influencing the photosynthesisconductance model (Figs. 1a,c). In this simulation, the biome-dependent physiological parameter controlling the maximum photosynthetic rate, $V_{\max }$ was the same as the "unadjusted" control run.

3) The third experiment (PV) simulated the case where the plant's physiological activity is down regulated as a result of long-term exposure to an elevated atmospheric $\mathrm{CO}_{2}$ concentration. The assimilation rates calculated for each grid point for the last $10 \mathrm{yr}$ of the $\mathrm{C}$ and $\mathrm{P}$ simulations were time averaged, and ratios were obtained $(\mathrm{C} / \mathrm{P})$ for each land grid point. These ratios were used to down regulate the photosynthetic activity by proportionally reducing the $V_{\max }$ values at every grid point. The expected result is that, at $2 \times \mathrm{CO}_{2}$, the assimilation rates in this experiment should approach those of the $\mathrm{C}$ case (Fig. 1b) and stomatal conductance to water vapor should be substantially reduced (Fig. 1c). The P and PV simulations show the sensitivity of climate to decreasing conductance in the absence of radiative forcing.

4) The fourth run, radiation-only ( $R$ ) case, is a conventional $2 \times \mathrm{CO}_{2}$ experiment in which only the atmospheric radiative fluxes are affected by the $2 \times$ $\mathrm{CO}_{2}$ atmosphere, whereas the land surface vegetation model "sees" only $1 \times \mathrm{CO}_{2}$. This experiment is useful to assess the impact of physical climate change on the vegetation physiological activity and to compare our results to those produced by other GCMs.

5) The radiation and physiology (RP) run is a combination of the $\mathrm{R}$ and $\mathrm{P}$ treatments; both the atmospheric radiation and the unadjusted physiology operate under $2 \times \mathrm{CO}_{2}$. This case illustrates the effect of doubled $\mathrm{CO}_{2}$ on unscaled physiology in conjunc- 
A : Land

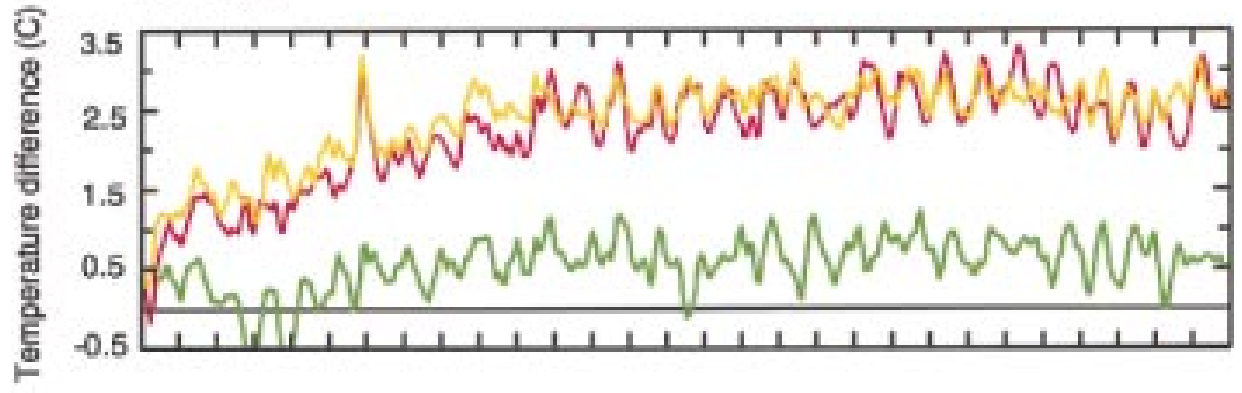

B : Land and ocean

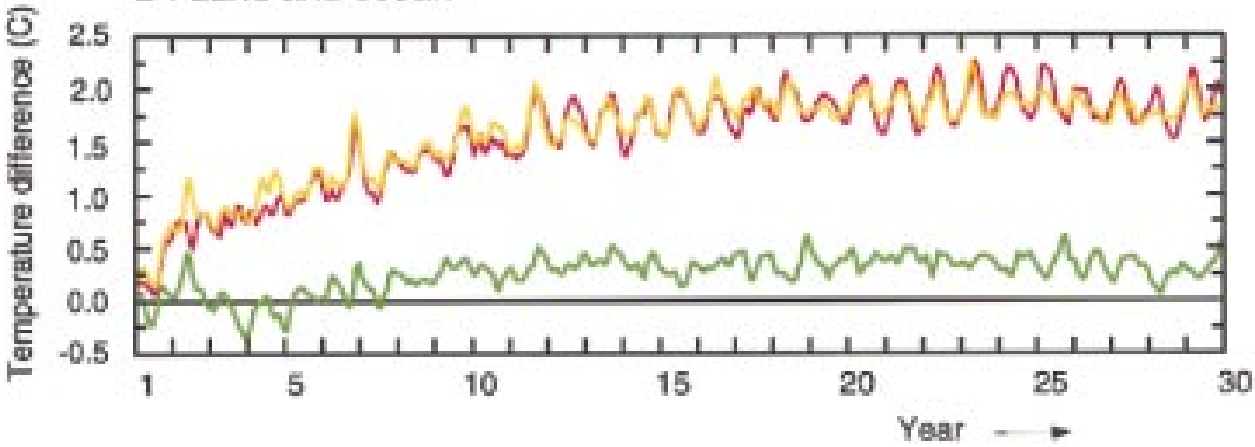

FIG. 3. Three-month running mean temperature difference (PV-C: green), (R-C: red), (RPV-C: orange) for (a) land points and (b) land and ocean points.

tion with conventional "greenhouse" radiative forcing.

6) The response of down-regulated physiology and radiative forcing is addressed in the RPV run. The assimilation fields obtained from the last $10 \mathrm{yr}$ of the RP and $\mathrm{C}$ experiments were averaged and their ratios were applied to scale down $V_{\max }$ in the same way as in the PV case. The RPV experiment was then run forward with down-regulated physiology and $2 \times \mathrm{CO}_{2}$ for both the atmospheric GCM and the vegetation model.

For all six experiments, global satellite data for 1987 were used to define land surface parameters at monthly intervals (Sellers et al. 1996c; Randall et al. 1996).

\section{Results and discussion}

\section{a. Model response}

Figure 3 shows the mean monthly surface air temperature response to increased $\mathrm{CO}_{2}$ for selected experiments: results for the PV, R, and RPV cases are displayed as differences from $\mathrm{C}$. The temperature increase due to the doubling of $\mathrm{CO}_{2}$ for the vegetation only (PV) is initially slow and shows almost no warming on the global scale during the first $6 \mathrm{yr}$ of integration. A significant warming observed over the tropical land was offset by a cooling in the middle and high northern latitudes regions during the same period, apparently re- lated to the model adjustment. After that, the land surface air temperature increased relatively fast to reach an equilibrium around year 20. The response of the global (land and ocean) surface air temperature paralleled the warming over land, although the globally averaged warming was weaker as a result of the oceanic thermal inertia. In both the R and RPV simulations, the mean temperature's response to the impulsively doubled $\mathrm{CO}_{2}$ concentration was almost instantaneous. The warming proceeded rapidly during the first $15 \mathrm{yr}$ of the simulations, then it increased more slowly, and finally approached an equilibrium around year 20. The tendency for PV to be warmer than C, and RPV to be warmer than R, is evident in Fig. 3 and will be discussed below. It is interesting to note at this point that interannual variability in the simulated air temperature is large enough at times to obscure the physiological effects.

\section{b. Diurnal cycle response}

Hourly time series of physiological and climate variables for selected locations were saved for the last 10 $\mathrm{yr}$ of the C, R, RP, and RPV simulations and 10-yr composite diurnal cycles were constructed using values over 310 cycles. Four grid cells have been chosen for discussion: one in the Amazon Basin representing a tropical forest in January (Fig. 4), a second in the North American temperate forest representing a mix of broad- 

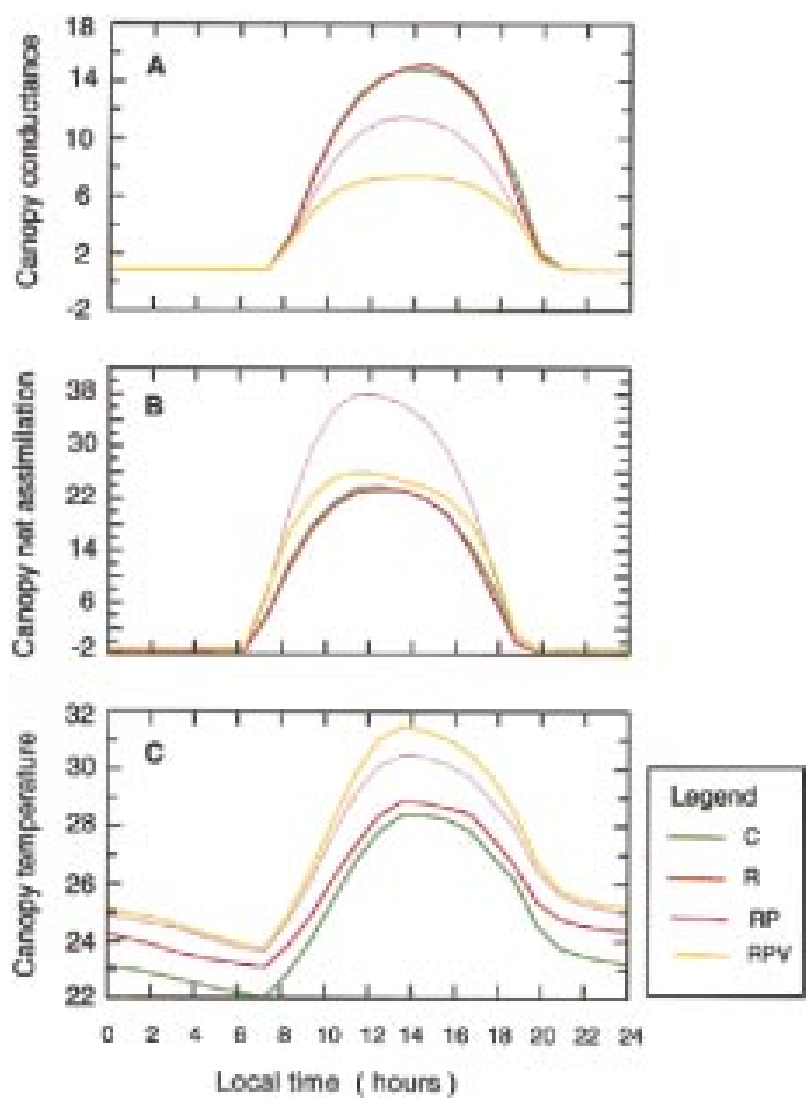

FIG. 4. Diurnal cycle composite (last $10 \mathrm{yr}$ of runs) for the Amazonian evergreen forest point in January: (a) canopy conductance $\left(\mathrm{mm} \mathrm{s}^{-1}\right)$, (b) canopy net assimilation ( $\mu$ moles $\left.\mathrm{m}^{-2} \mathrm{~s}^{-1}\right)$, and (c) canopy temperature $\left({ }^{\circ} \mathrm{C}\right)$.

leaf and needleleaf trees in July (Fig. 5), a third in the North American boreal needleleaf forest region in July (Fig. 6), and finally a grid cell representing the Sahelian region with $\mathrm{C} 4$ vegetation in July (Fig. 7). (See Table 1 for exact geographical locations.) For each of these sites we show the net carbon assimilation, the canopy conductance, and the canopy temperature during the peak of the growing season, for the four experiments mentioned above.

Diurnal cycles were not saved for the P and PV cases and so cannot be discussed here. To a large extent, however, their behavior can be inferred from the RP and RPV cases as compared to run R.

For run $\mathrm{C}$, the peak photosynthetic rate of the canopy depends in large part (nearly proportionally) on the fraction of photosynthetically active radiation absorbed by the canopy (FPAR) and on the physiological capacity $\left(V_{\max }\right)$ of the leaves in the canopy. The tropical forest has approximately twice the FPAR of the boreal forest point (0.93 vs 0.48 ) and about two-thirds more photosynthetic capacity per leaf. This results in peak photosynthetic rates three times greater in tropical versus needleleaf forests. The peak rate for the boreal forest point did not occur at midday as it did for the tropical
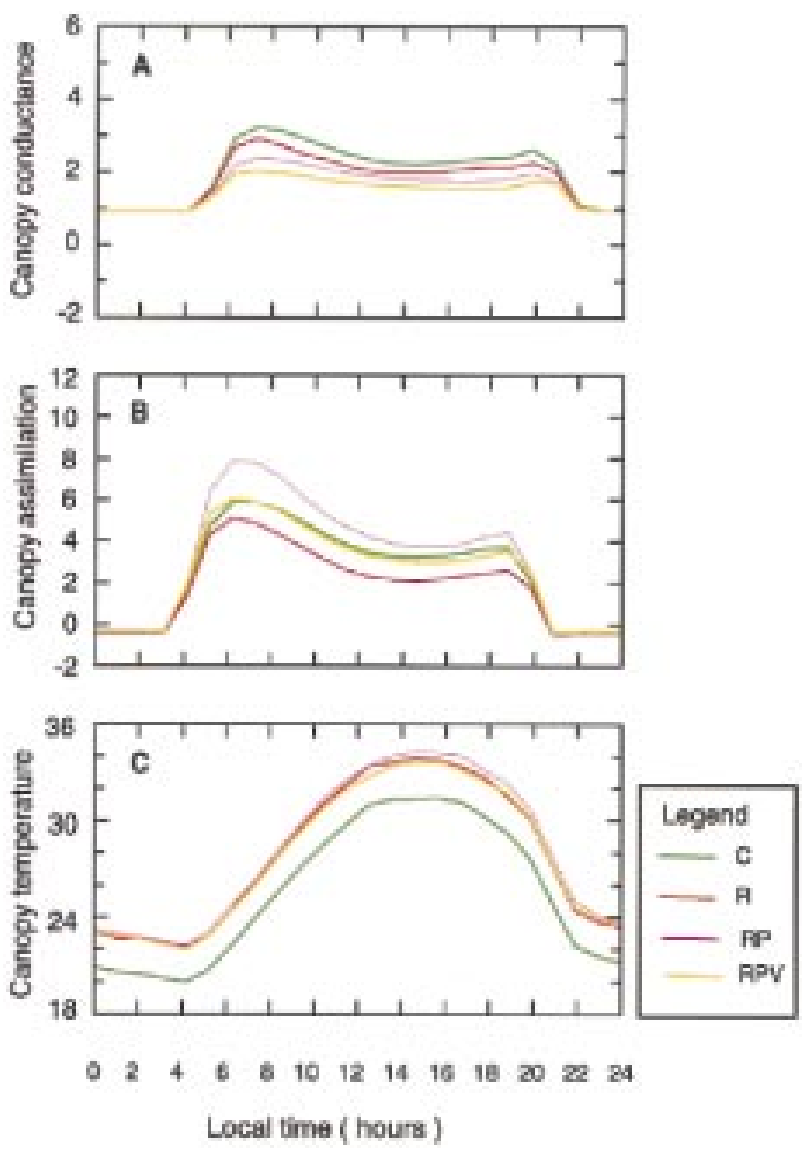

FIG. 5. Diurnal cycle composite (last $10 \mathrm{yr}$ of runs) for the Canadian evergreen forest point in July: (a) canopy conductance $\left(\mathrm{mm} \mathrm{s}^{-1}\right)$, (b) canopy net assimilation ( $\mu$ moles $\mathrm{m}^{-2} \mathrm{~s}^{-1}$ ), and (c) canopy temperature $\left({ }^{\circ} \mathrm{C}\right)$.

forest, because midday temperatures in the former were high enough to cause physiological stress. The $\mathrm{C} 4$ grid point has half the FPAR (0.42) of the tropical forest but produces a similar rate of photosynthesis because of greater stimulation of $\mathrm{C} 4$ photosynthesis by warm temperatures, as described in Collatz et al. (1992). Upon doubling $\mathrm{CO}_{2}$, peak photosynthesis increased for C3 biomes by $61 \%$ in the tropical forest, $53 \%$ in midlatitude mixed evergreen-deciduous forest, and $23 \%$ in the boreal forest. Warmer regions tended to show larger $\mathrm{CO}_{2}$ stimulation. The Sahel point showed only $10 \%$ increase since $\mathrm{C} 4$ plants are relatively insensitive to external atmospheric $\mathrm{CO}_{2}$ concentration as expected from the theoretical calculations (Fig. 1a). Down regulation caused photosynthesis to decrease to close to the control rate for $\mathrm{C} 3$ biomes. The small stimulation of the $\mathrm{C} 4$ grid cell by the $\mathrm{CO}_{2}$ increase resulted in little down-regulation response. The plateau and depression of photosynthesis at midday for the mixed and boreal forest points is a result of a reduction in the photosynthetic capacity $\left(V_{\max }\right)$ in response to temperature and soil moisture stress.

Canopy conductance also followed what was ex- 

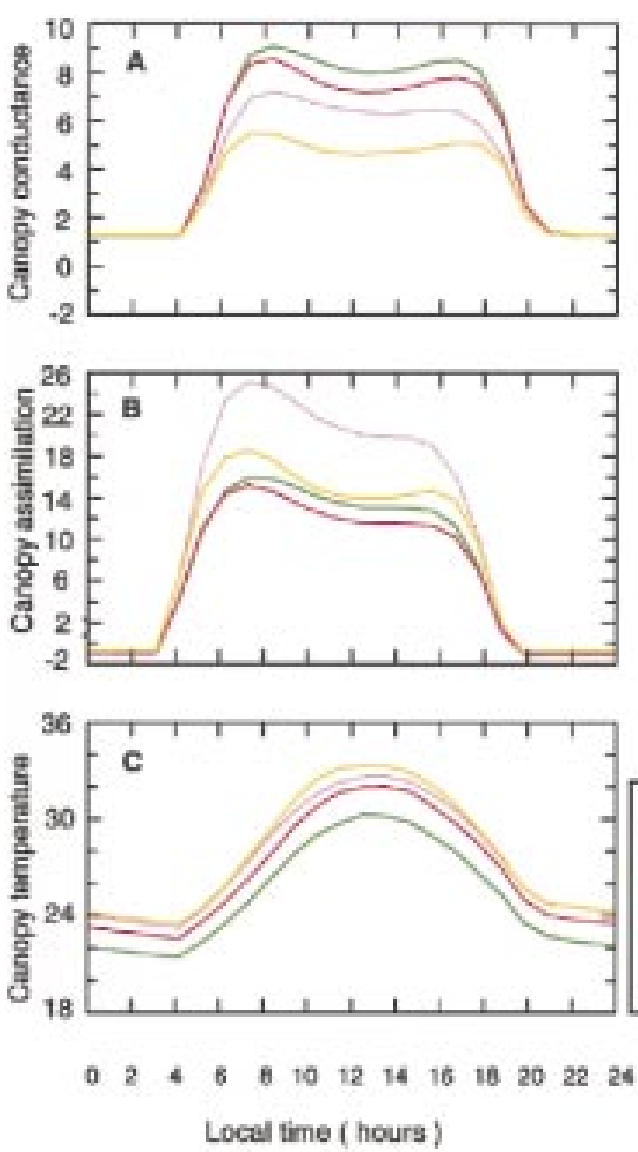

FIG. 6. Same as Fig. 5 except for the northeastern United States mixed forest point.

pected from the model structure (Fig. 1c) with a pattern of decreasing values as high $\mathrm{CO}_{2}$ and down regulation were imposed. The RP case resulted in about a $20 \%$ reduction whereas the RPV case produced about 30\%$45 \%$ decrease in peak canopy conductance for all C3 points. For the $\mathrm{C} 4$ point, conductance fell by about half in the RP case and was not affected by the scaling procedure. Since conductance is a linear function of net photosynthesis as shown in Eq. (1), stresses that limit photosynthesis are reflected in conductance.

Canopy temperatures are determined by the climate, the physiological state of the vegetation, and the feedback between them. In general, radiative forcing alone (R) increased both day and night temperatures. Canopy conductance decreased in response to $\mathrm{CO}_{2}$ doubling (RP, RPV), causing transpirational cooling to decrease and daytime canopy temperature to increase for all four grid cells. Thus local responses of $2 \times \mathrm{CO}_{2}$ induced physiological and radiative forcing tend to determine the local temperature patterns. The extent to which temperatures increased, however, depended on the location and time of day. For the tropical forest and C4 short vegetation points, photosynthesis and conductance were slightly affected by the radiative forcing-induced in-
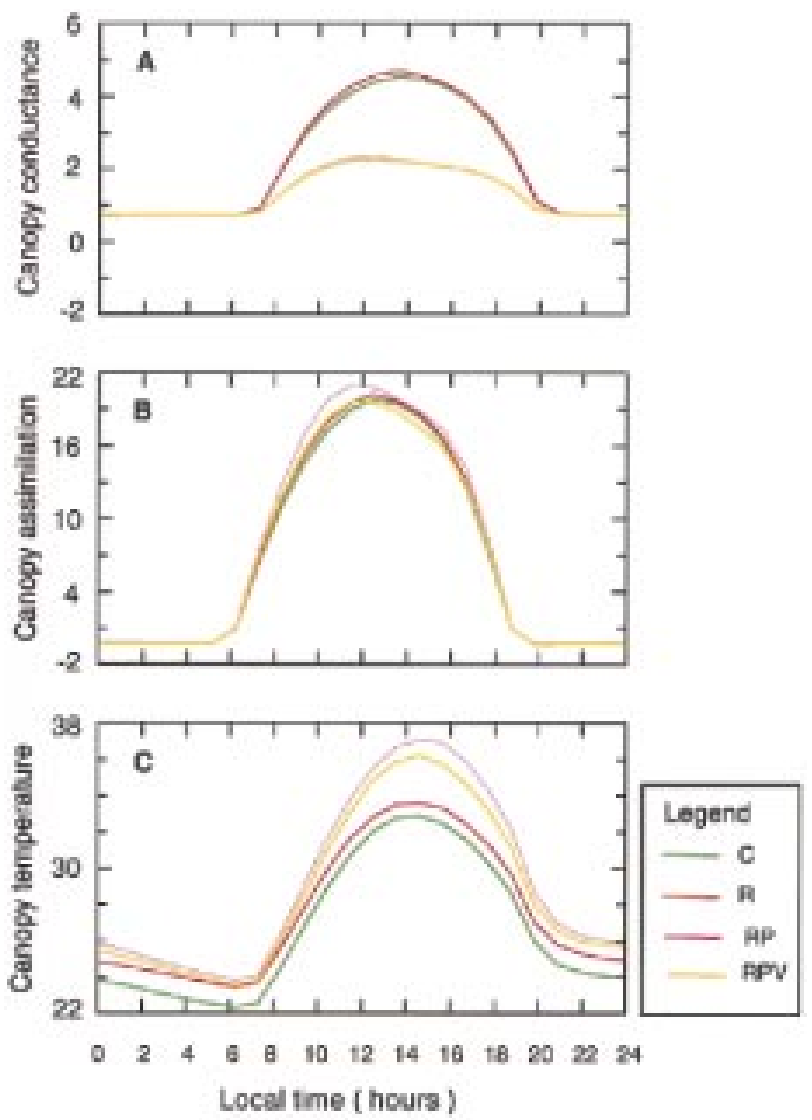

FIG. 7. Same as Fig. 5 except for the Sahelian shrubs with ground cover point.

crease in temperature. On the other hand, the middlelatitude and boreal forest points showed a decrease in physiological activity, especially at midday, resulting from a combination of high temperature, low humidity, and water stress. The effect of $\mathrm{R}$ on the diurnal response of canopy temperature for these sites depended upon the degree of high-temperature stress. Figure 8 shows the July daytime and nighttime canopy temperature differences between the $\mathrm{R}$ and $\mathrm{C}$ experiments (Fig. 8a), as well as the high-temperature stress level during the $\mathrm{R}$ and $\mathrm{C}$ cases (Fig. 8b), for the four selected locations. The high-temperature stress function represents the degree to which the photosynthetic capacity $\left(V_{\max }\right)$ is scaled down due to high-temperature stress effects on photosynthesis. The high-temperature stress function depends on canopy temperature and biome-dependent parameters and varies between 0 (maximum stress) and

TABLE 1. Locations of the selected grid cells.

\begin{tabular}{lcc}
\hline \hline \multicolumn{1}{c}{ Name } & Latitude & Longitude \\
\hline Amazonian evergreen forest & $3.6^{\circ} \mathrm{S}$ & $63.0^{\circ} \mathrm{W}$ \\
Northeastern U.S. mixed forest & $46.8^{\circ} \mathrm{N}$ & $72.0^{\circ} \mathrm{W}$ \\
Canadian evergreen needleleaf & $54.0^{\circ} \mathrm{N}$ & $99.0^{\circ} \mathrm{W}$ \\
Sahelian shrubs with ground cover $\left(\mathrm{C}_{4}\right)$ & $10.8^{\circ} \mathrm{N}$ & $09.0^{\circ} \mathrm{E}$ \\
\hline
\end{tabular}



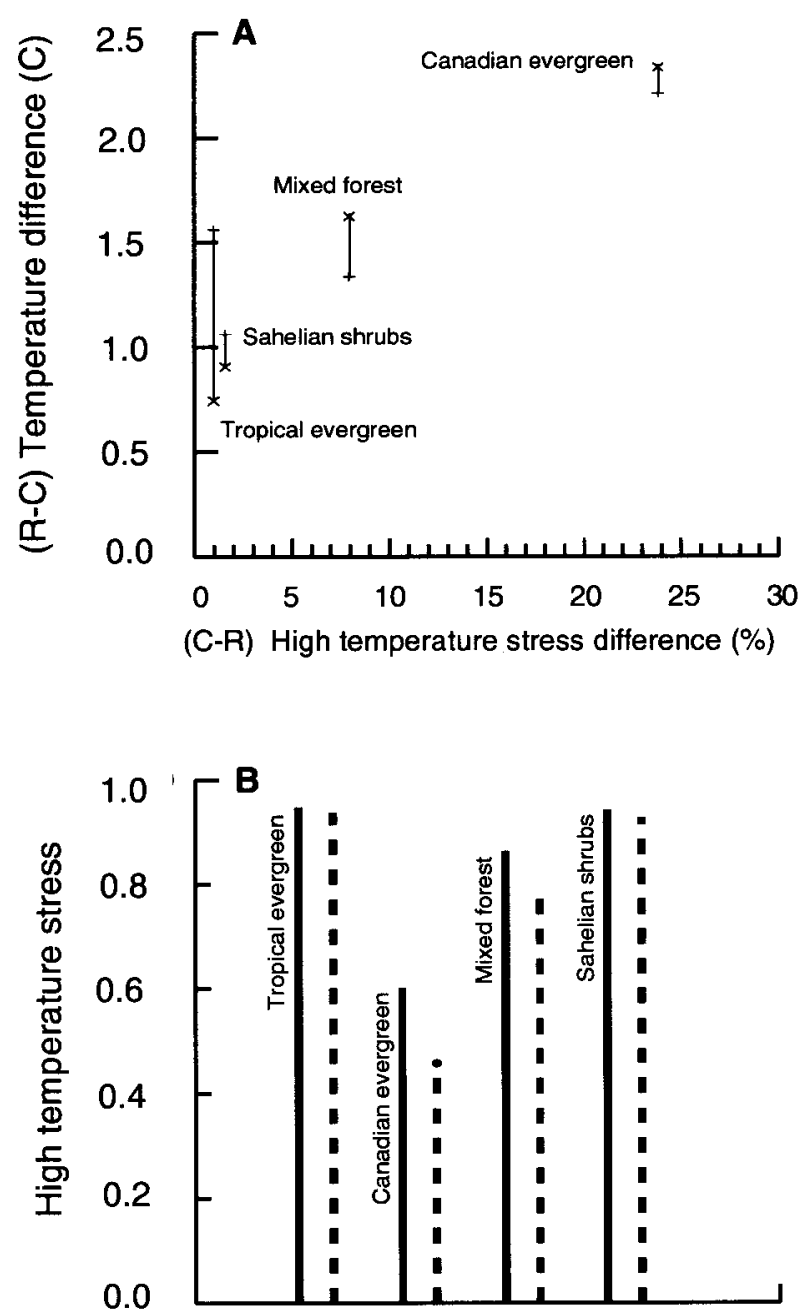

\section{Selected locations}

FIG. 8. (a) Daytime $(\times)$ and nighttime $(+)$ temperature difference $\left({ }^{\circ} \mathrm{C}\right)$ vs high temperature stress difference. (b) High-temperature stress (dimensionless) for the selected locations, solid (C case), dashed ( $\mathrm{R}$ case).

1 (no stress) (Sellers et al. 1996c). In locations where the vegetation was stressed (boreal and temperate forest points), the canopy temperature difference between $\mathrm{R}$ and $\mathrm{C}$ was larger during the day than at night. For these points, the daytime temperatures inhibited photosynthesis resulting in stomatal closure, and consequently increasing the temperature over and above that caused by radiative forcing. On the other hand, in areas that experienced little or no stress, the temperature difference between the $\mathrm{R}$ and $\mathrm{C}$ cases was substantially smaller during the day than during the night, especially in the tropical forest where the nighttime temperature difference was about twice that of the daytime (Fig. 8a), an effect not discernable in the daily mean temperatures. For example, the daily mean temperature increase between the $\mathrm{C}$ and $\mathrm{R}$ cases in the tropical forest is about $1.16^{\circ} \mathrm{C}$, but while the nightime difference is $1.56^{\circ} \mathrm{C}$, the daytime difference is only $0.76^{\circ} \mathrm{C}$. This indicates that vegetation is a central element in the modulation of the diurnal temperature cycle in an enhanced $\mathrm{CO}_{2}$ environment and may play an important role in the determination of regional climates. Observational data indicate that over the last $40 \mathrm{yr}$, minimum diurnal temperatures have increased over land while the maximum have not, leading to a mean reduction in the diurnal temperature range (Karl et al. 1993). Our results show that the diurnal temperature range could decrease under greenhouse forcing as a result of increased evaporative cooling during the day when physiology is active, but not at night when stomata are closed (Fig. 4). The reverse is predicted, however, if vegetation is stressed causing greater reductions in latent heat flux during the day and an increase in the diurnal temperature range (Fig. 5).

In general, the temperature dependence of photosynthesis is consistent with the temperature experienced during the growing season (Berry and Bjorkman 1980). In other words, the photosynthetic apparatus of warm climate vegetation can tolerate high temperatures more readily than can that of cool climate vegetation. The reverse is true for low temperatures. In SiB2 the hightemperature stress parameters are set to be consistent with the current observed climate for various biomes. For example, the high-temperature stress factor will cause photosynthesis to be $50 \%$ inhibited at $30^{\circ} \mathrm{C}$ for needleleaf forests. Therefore midday maximum temperatures of around $34^{\circ} \mathrm{C}$ for the boreal grid point in the $\mathrm{R}$ case (Fig. 6a) produced substantial inhibition of photosythesis and associated reductions in conductance. High levels of temperature stress during the growing season indicate that the prescribed vegetation cover is not consistent with the simulated greenhouse climate. If changes in the climate as a result of greenhouse warming were slow enough, we would expect that the temperature tolerance of the vegetation would adjust either through acclimation or through species change so that the growing season stress is minimized. If, however, warming occurs faster than the vegetation response, then the increased stress predicted in these simulations is more plausible.

\section{c. Monthly response}

This section describes monthly mean differences, over the last 10 simulated years, between the five experiments and the control, aggregated, during the growing season, for three biome groupings: tropical forests (Fig. 9), tropical short vegetation (Fig. 10), evergreen needleleaf forests (Fig. 11), and finally for all vegetated land points (Fig. 12). The biome average change in the photosynthetic rate as a result of physiological and radiative responses to $2 \times \mathrm{CO}_{2}$ are as expected from the diurnal responses and theoretical discussion; large stimulation in the physiology cases ( $\mathrm{P}, \mathrm{RP})$, positive but smaller increases for the down-regulated cases (PV, 

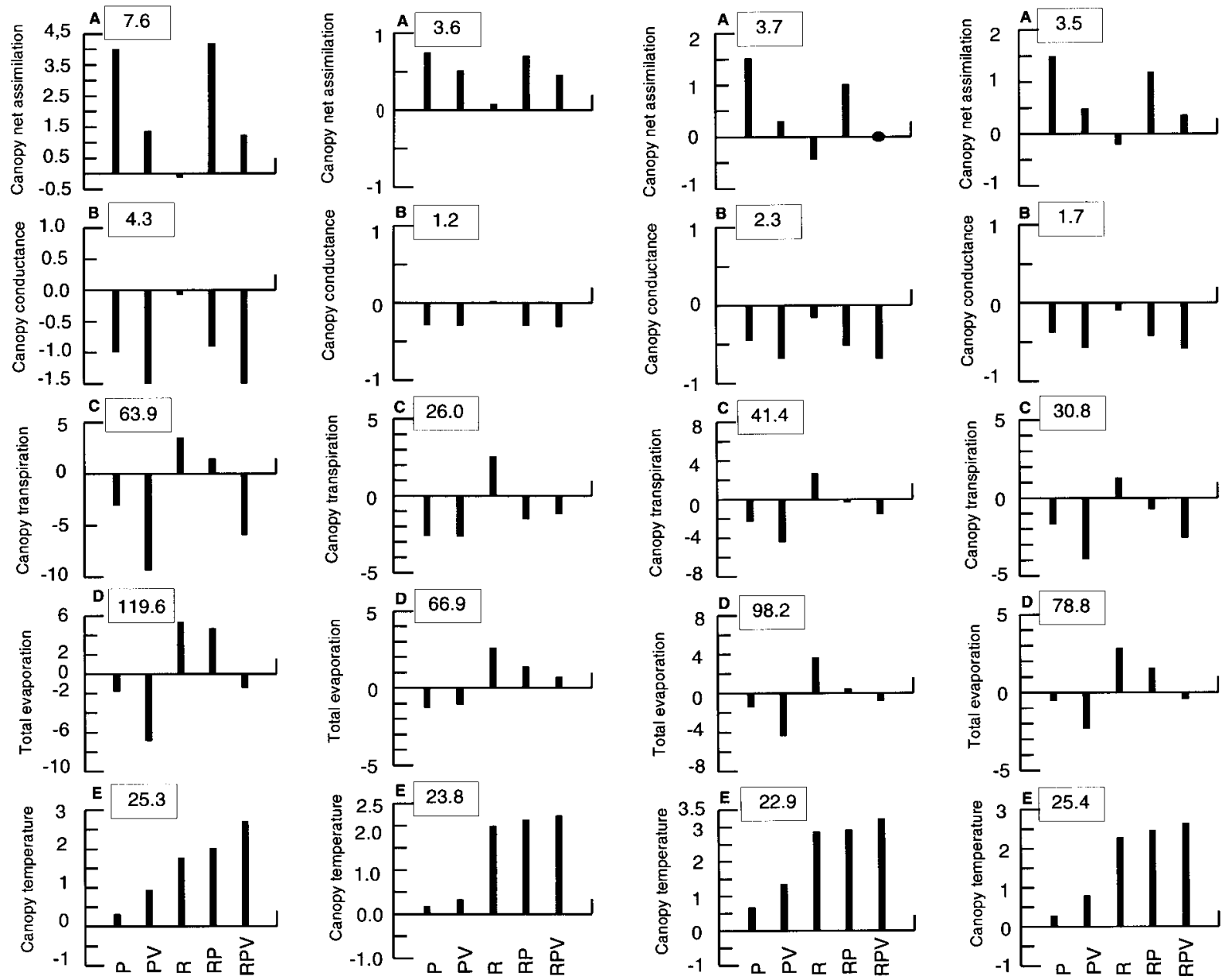

Fig. 9. (far left) Annual-mean difference (experiment minus control, last $10 \mathrm{yr}$ of runs) averaged over all tropical evergreen forest points for (a) canopy net assimilation ( $\mu$ moles $\mathrm{m}^{-2} \mathrm{~s}^{-1}$ ), (b) canopy conductance $\left(\mathrm{mm} \mathrm{s}^{-1}\right)$, (c) canopy transpiration (W $\mathrm{m}^{-2}$ ), (d) total evaporation $\left(\mathrm{W} \mathrm{m}^{-2}\right)$, and (e) canopy temperature $\left({ }^{\circ} \mathrm{C}\right)$. Values in boxes are control means. Fig. 10 (center left) July mean difference (experiment minus control, last $10 \mathrm{yr}$ of runs) averaged over all short vegetation- $\mathrm{C}_{4}$ points for (a) canopy net assimilation $\left(\mu \mathrm{moles}^{-2} \mathrm{~s}^{-1}\right)$, (b) canopy conductance $\left(\mathrm{mm} \mathrm{s}^{-1}\right)$, (c) canopy transpiration $\left(\mathrm{W} \mathrm{m}^{-2}\right)$, (d) total evaporation $\left(\mathrm{W} \mathrm{m}^{-2}\right)$, and (e) canopy temperature $\left({ }^{\circ} \mathrm{C}\right)$. Values in boxes are control means. Fig. 11 (center right) Same as in Fig. 10 except for needleleaf evergreen forest. FIg. 12 (far right) Same as in Fig. 10 except for all vegetated land points.

RPV), and small inhibition due to radiative forcing alone (R), especially for northern evergreen forests (Fig. 11a). The doubling of the $\mathrm{CO}_{2}$ concentration led to a mean stimulation of about $53 \%$ for the tropical forest, versus $42 \%$ for the northern needleleaf forest and $22 \%$ for the $\mathrm{C} 4$ vegetation. Similarly, canopy conductance decreased relative to the control for all three biome types and over all land points, with the strongest reductions in the down-regulated cases. Since canopy conductance directly controls the transpiration, which is a major component of the total latent heat flux from vegetated surfaces, the reduction in conductance is mirrored in the transpiration and total latent heat flux. Radiative forcing alone $(\mathrm{R})$ caused transpiration and total evapotranspiration to increase, whereas physiological responses more than compensated for these increases leading to reductions to below the control for all biomes except for the $\mathrm{C} 4$ vegetation where the total evapotranspiration is slightly above the control value in the RPV case. As expected, reduced latent heat flux from the canopy is associated with increased canopy temperature. A striking result, however, is that the $\mathrm{R}$ case caused the temperature to increase by about $2.9 \mathrm{~K}$ over the control in the northern forest (Fig. 11e), that is about $1.2 \mathrm{~K}$ more than its effect in the tropical forest. This larger heating in the north seems to be related to a higher temperature stress, which resulted in an inhibition of photosynthesis (Fig. 11a) and consequently decreased canopy conductance. This has limited the increase in transpiration and forced more of the available energy to be shunted into sensible heat flux. On the other hand, when compared to the $\mathrm{R}$ case the tropical forest showed greater warming in response to the combination of radiative and physiological (RPV) forcing than the needleleaf evergreen 


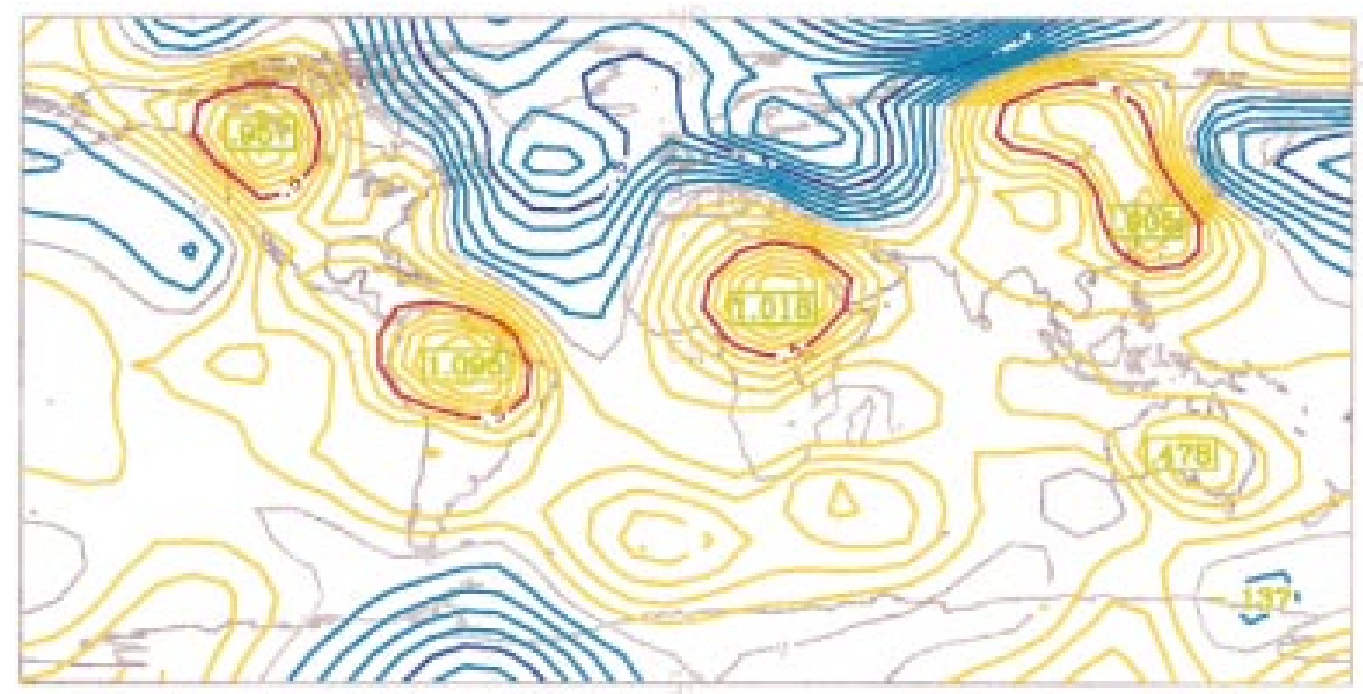

FIG. 13. Mean temperature difference $\left({ }^{\circ} \mathrm{C}\right)(\mathrm{RPV}-\mathrm{R}$, last $10 \mathrm{yr}$ of runs). Contour from -1.3 to 1.0 by 0.1 .

forest $(0.7 \mathrm{~K}$ vs $0.3 \mathrm{~K})$, although with respect to the control the northern forest responded with a larger temperature increase. This is because the $\mathrm{R}$ run produced more warming in the boreal forest than in the tropical forest. Furthermore, the responses of temperature to physiological and radiative forcings were almost additive for the tropical forest $(\mathrm{R}+\mathrm{PV}=2.7 \mathrm{~K}$ vs $\mathrm{RPV}$ $=2.7 \mathrm{~K})$ and the $\mathrm{C} 4$ biome $(\mathrm{R}+\mathrm{PV}=2.3 \mathrm{~K}$ vs $\mathrm{RPV}$ $=2.2 \mathrm{~K}$ ), whereas this was not the case for the northern forest $(\mathrm{R}+\mathrm{PV}=4.3 \mathrm{~K}$ vs $\mathrm{RPV}=3.2 \mathrm{~K})$.

The (RPV-R) temperature difference distribution during the growing season shows the land vegetated regions as major heat sources (Fig. 13). The entire landmass underwent a warming over and above the radiative effect except for the western European region where the large-scale climate overwhelmed local vegetation effects.

Thus it can be seen from the hourly and monthly data that the response characteristics of the physiological model tend to dominate during the growing season. This is not necessarily the case outside the growing season when the physiology does not play a strong role in the local climate. Comparing January temperatures for a
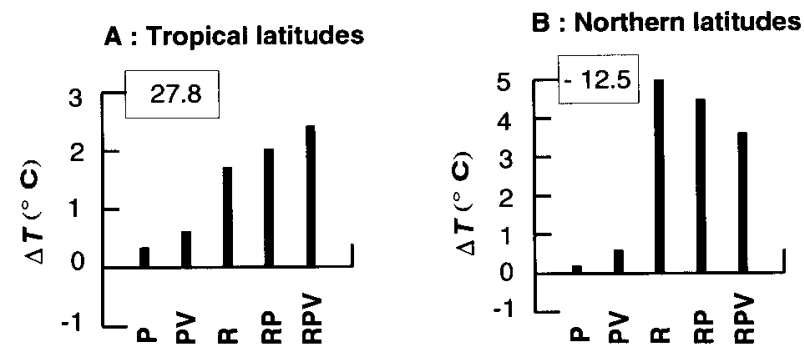

FIG. 14. January mean temperature difference (last $10 \mathrm{yr}$ of runs) for (a) tropical latitude band $\left(14.4^{\circ} \mathrm{S}-14.4^{\circ} \mathrm{N}\right)$ and (b) northern latitude band $\left(50.4^{\circ}-70.0^{\circ} \mathrm{N}\right)$. Values in boxes are control means. tropical latitude band $\left(14.4^{\circ} \mathrm{N}-14.4^{\circ} \mathrm{S}\right)$ with that for a high northern latitude band $\left(50.4^{\circ}-70^{\circ} \mathrm{N}\right)$ shows some unexpected results. During the winter, when the northern vegetation is not physiologically active, the tropical regions continue to warm as a response to high $\mathrm{CO}_{2}$ and down regulation, but a cooling occurs in the northern latitudes between the R, RP, and RPV cases as can be seen in Figs. 14a,b. The perturbation in the tropical forest canopy conductance far away from this region has caused local temperatures to decrease. Obviously, such results cannot be explained by physiological responses alone but must take in consideration the global atmospheric circulation. We intend to investigate this further using high-resolution runs currently under way.

\section{d. Annual response}

The effects of radiative and physiological responses to $\mathrm{CO}_{2}$ on the annual mean state of the physiology and the climate are discussed in this section. Annual means are, generally, consistent with the conclusions of the preceding analysis, but contain less information about the the underlying processes. Table 2 shows the annualmean values and changes relative to the control, over the last $10 \mathrm{yr}$ of each experiment, for the assimilation, canopy conductance, evapotranspiration, precipitation, and surface air temperature, averaged for selected latitudinal bands as well as over all land points and over the entire globe.

The impact of the purely radiative $(\mathrm{R})$ perturbation on assimilation was small at global scale, although some inhibition of photosynthetic rates was observed in middle and high northern latitudes. The needleleaf evergreen biome type, which is a major component in the northern latitude band $\left(50^{\circ}-72^{\circ} \mathrm{N}\right)$, experienced increased high-temperature stress in the middle of the 
TABLE 2. Summary of results from the six experiments described in test: C-control $\left(1 \times \mathrm{CO}_{2}\right.$ for radiation and physiology $) ; \mathrm{P}\left(1 \times \mathrm{CO}_{2}\right.$ for radiation, $2 \times \mathrm{CO}_{2}$ for physiology); $\mathrm{PV}\left(1 \times \mathrm{CO}_{2}\right.$ for radiation, $2 \times \mathrm{CO}_{2}$ for down-regulated physiology); $\mathrm{R}\left(2 \times \mathrm{CO}_{2}\right.$ for radiation, $1 \times \mathrm{CO}_{2}$ for physiology); $\mathrm{RP}\left(2 \times \mathrm{CO}_{2}\right.$ for radiation, $2 \times \mathrm{CO}_{2}$ for physiology); $\mathrm{RPV}\left(2 \times \mathrm{CO}_{2}\right.$ for radiation, $2 \times \mathrm{CO}_{2}$ for down-regulated physiology). Values in table are means for the last $10 \mathrm{yr}$ of the 30 -yr simulations. The values in parentheses are the percent differences from $\mathrm{C}$ except in the case of surface air temperature, which are the differences from C.

\begin{tabular}{|c|c|c|c|c|c|}
\hline \multirow[b]{2}{*}{ Experiment } & \multicolumn{5}{|c|}{ Location } \\
\hline & $\begin{array}{c}\text { Tropics } \\
14.4^{\circ} \mathrm{S}-14.4^{\circ} \mathrm{N}\end{array}$ & $\begin{array}{l}\text { Midlatitudes } \\
28.8-50.4^{\circ} \mathrm{N}\end{array}$ & $\begin{array}{l}\text { North latitudes } \\
50.4-72.0^{\circ} \mathrm{N}\end{array}$ & All land points & $\begin{array}{c}\text { Global } \\
\text { land }+ \text { ocean }\end{array}$ \\
\hline \multicolumn{6}{|c|}{ Assimilation $\left(\mu \mathrm{mol} \mathrm{m} \mathrm{m}^{-2} \mathrm{~s}^{-1}\right)$} \\
\hline $\mathrm{C}$ & 6.04 & 1.77 & 1.67 & 2.65 & \\
\hline $\mathrm{P}$ & $7.96(31.7)$ & $2.62(48.3)$ & $2.26(35.6)$ & $3.59(35.3)$ & \\
\hline PV & $6.87(13.8)$ & $1.96(10.8)$ & $1.76(6.0)$ & $2.93(10.6)$ & \\
\hline $\mathrm{R}$ & $6.08(0.6)$ & $1.72(-2.5)$ & $1.63(-2.0)$ & $2.65(0.0)$ & \\
\hline $\mathrm{RP}$ & $8.10(35.1)$ & $2.53(43.4)$ & $2.25(35.0)$ & $3.59(35.5)$ & \\
\hline RPV & $6.71(11.0)$ & $2.02(14.1)$ & $1.81(8.9)$ & $2.94(11.0)$ & \\
\hline \multicolumn{6}{|c|}{ Canopy conductance $\left(\mathrm{mm} \mathrm{s}^{-1}\right)$} \\
\hline $\mathrm{C}$ & 2.79 & 0.79 & 0.92 & 1.21 & \\
\hline $\mathrm{P}$ & $2.06(-26.1)$ & $0.61(-23.4)$ & $0.68(-25.9)$ & $0.90(-25.1)$ & \\
\hline PV & $1.82(-34.8)$ & $0.49(-38.3)$ & $0.59(-35.7)$ & $0.78(-35.2)$ & \\
\hline $\mathrm{R}$ & $2.81(0.6)$ & $0.79(-0.9)$ & $0.91(-0.6)$ & $1.21(0.2)$ & \\
\hline $\mathrm{RP}$ & $2.12(-24.1)$ & $0.61(-23.8)$ & $0.69(-24.5)$ & $0.92(-23.8)$ & \\
\hline RPV & $1.79(-35.9)$ & $0.51(-35.9)$ & $0.62(-32.4)$ & $0.79(-34.1)$ & \\
\hline \multicolumn{6}{|c|}{ Evapotranspiration $\left(\mathrm{W} \mathrm{m}^{-2}\right)$} \\
\hline $\mathrm{C}$ & 100.8 & 49.6 & 38.6 & 58.9 & 96.0 \\
\hline $\mathrm{P}$ & $96.7(-4.0)$ & $49.3(-0.6)$ & $37.7(-2.2)$ & $57.6(-2.3)$ & $95.8(-0.2)$ \\
\hline PV & $96.5(-4.2)$ & $48.1(-3.1)$ & $37.0(-4.1)$ & $56.9(-3.5)$ & $96.0(0.1)$ \\
\hline $\mathrm{R}$ & $105.9(5.1)$ & $52.3(5.4)$ & $41.2(6.8)$ & $62.3(5.8)$ & $100.1(4.2)$ \\
\hline $\mathrm{RP}$ & $102.6(1.9)$ & $51.5(3.8)$ & $39.9(3.4)$ & $60.9(3.3)$ & $99.9(4.0)$ \\
\hline RPV & $100.0(-0.8)$ & $50.4(1.6)$ & $39.0(1.0)$ & $59.1(0.3)$ & $99.1(3.3)$ \\
\hline \multicolumn{6}{|c|}{ Precipitation $\left(\mathrm{mm} \mathrm{day}^{-1}\right)$} \\
\hline $\mathrm{C}$ & 4.36 & 2.70 & 2.35 & 2.90 & 3.29 \\
\hline $\mathrm{P}$ & $4.34(-0.4)$ & $2.69(-0.2)$ & $2.33(-1.1)$ & $2.89(-0.3)$ & $3.28(-0.2)$ \\
\hline PV & $4.35(-0.2)$ & $2.78(3.0)$ & $2.34(-0.6)$ & $2.94(1.3)$ & $3.29(0.1)$ \\
\hline $\mathrm{R}$ & $4.58(5.0)$ & $2.91(7.7)$ & $2.54(7.8)$ & $3.10(7.0)$ & $3.43(4.2)$ \\
\hline $\mathrm{RP}$ & $4.58(5.0)$ & $2.89(6.8)$ & $2.49(5.8)$ & $3.09(6.5)$ & $3.42(4.0)$ \\
\hline RPV & $4.45(2.1)$ & $2.79(3.1)$ & $2.43(3.4)$ & $2.99(3.0)$ & $3.40(3.3)$ \\
\hline \multicolumn{6}{|c|}{ Surface air temperature $\left({ }^{\circ} \mathrm{C}\right)$} \\
\hline $\mathrm{C}$ & 28.1 & 17.4 & 4.8 & 19.6 & 18.5 \\
\hline $\mathrm{P}$ & $28.5(0.4)$ & $17.7(0.3)$ & $5.1(0.3)$ & $19.8(0.3)$ & $18.7(0.1)$ \\
\hline PV & $28.8(0.7)$ & $17.9(0.5)$ & $5.9(1.1)$ & $20.2(0.7)$ & $18.9(0.3)$ \\
\hline $\mathrm{R}$ & $29.8(1.7)$ & $20.0(2.6)$ & $8.8(4.0)$ & $22.2(2.6)$ & $20.4(1.9)$ \\
\hline $\mathrm{RP}$ & $30.2(2.1)$ & $20.3(2.9)$ & $8.7(3.9)$ & $22.4(2.8)$ & 20.5 (1.9) \\
\hline RPV & $30.6(2.6)$ & $20.0(2.6)$ & $8.1(3.3)$ & $22.2(2.7)$ & $20.4(1.8)$ \\
\hline
\end{tabular}

growing season as a result of warming due to radiative forcing at $2 \times \mathrm{CO}_{2}$ (see also Figs. 6 and 11). On the annual mean, however, the warming in spring and fall resulted in less low-temperature stress (not shown) and, therefore, compensated for much of the mid-growing season high-temperature inhibition of assimilation and conductance. The assimilation fields resulting from the $\mathrm{C}$ and $\mathrm{R}$ cases were almost identical for the tropical regions where no significant temperature stress occurred (Figs. 4, 7, 9, and 10). The P and RP cases had significantly higher assimilation values than did their $1 \times$ $\mathrm{CO}_{2}$ counterparts, the $\mathrm{C}$ and $\mathrm{R}$ cases, respectively. The mean relative differences in assimilations for the $\mathrm{P}$ and RP cases in the tropical band appear smaller than their corresponding values in the middle and high latitudes. This is due in part to the presence of $\mathrm{C} 4$ biomes in this zone, which exhibit relatively slight responses to $2 \times$
$\mathrm{CO}_{2}$. The down regulation of carbon assimilation is slightly higher $(10 \%)$ than the control indicating that the scaling in the PV and RPV treatments was not complete, mainly because assimilation is enhanced at elevated $\mathrm{CO}_{2}$ concentrations in $\mathrm{C} 3$ plants at low solar radiation intensity (e.g., in the mornings and evenings) when $V_{\max }$ is not limiting. The overall effect of the down regulation of the physiology was to reduce the stomatal conductance by about $35 \%$ relative to the control, whereas the unadjusted treatments resulted in reductions of the order of $25 \%$. This range of responses is in good agreement with some laboratory and field $2 \times \mathrm{CO}_{2}$ experiments (see, e.g., Field et al. 1992; Morison 1987). There is a small difference between the stomatal conductance values in the $\mathrm{C}$ and $\mathrm{R}$ experiments, which is consistent with the annual mean assimilation rate. Canopy conductance and assimilation generally decrease 
away from the equator, following the environmental and vegetation density gradients. Thus we expected and obtained the largest physiological impacts of $2 \times \mathrm{CO}_{2}$ on evapotranspiration rates in the Tropics. The physiological effects of $\mathrm{P}$ and PV act to reduce the evapotranspiration rates as the stomates close, whereas in the $\mathrm{R}$ run, the increase in the net radiation at the earth's surface boosted evapotranspiration. The evapotranspiration was then progressively reduced from $\mathrm{R}$ to $\mathrm{RP}$ and to RPV so that ultimately its global mean over land returned approximately to the control value. The additional available energy resulting from the radiative response to 2 $\times \mathrm{CO}_{2}$ was released as sensible heat, causing a further increase in air temperature in the absence of nonlocal effects. This is an important result that could otherwise not have been seen in conventional greenhouse simulations that do not include the vegetation physiological effects.

For all parts of the earth the physiological effects $(\mathrm{P}$, $\mathrm{PV}$ ) on precipitation were small compared to those of the radiative treatments. Precipitation increased significantly in the $\mathrm{R}$ case, in line with most other GCMdoubled $\mathrm{CO}_{2}$ studies, then fell off slightly in the RP case, and was further reduced in the RPV case. A global increase of the precipitation rate of about 3\%, with respect to the control, was obtained in the RPV case.

The annual-mean surface temperature increased everywhere as $\mathrm{CO}_{2}$ fertilization and down regulation were imposed (P, PV). The effects of physiology (P, PV) were generally small compared to those of the radiative forcing alone ( $\mathrm{R}$ run) and are consistent with the reduction in conductance and evapotranspiration. The maximum temperature increase in the $\mathrm{R}$ run is obtained in the northern latitudes, which is in line with previous greenhouse studies. In the Tropics, where local effects are dominant, the annual-mean surface temperature mirrored the responses seen in the diurnal and monthly results; that is, an additional warming was obtained as the physiology was acting along with the radiative forcing. In the northern latitudes, however, although physiological responses to $2 \times \mathrm{CO}_{2}$ had the expected impact during the growing season, the boreal winter climate change induced by nonlocal physiological responses caused the RPV case to be cooler than the R case. The overall effect on the annual-mean temperature over that region is a cooling of about $0.7 \mathrm{~K}$ in response to global down regulation of conductance.

A Student's t-test was performed on the time series of the globally averaged annual-mean surface temperature to determine whether the temperature differences obtained between each experiment and the control could be accounted for by the natural variability of the coupled model. The various $t$ values obtained for each experiment versus the control are summarized in Table 3 . The limiting $t$ value for a $95 \%$ confidence level is 1.67 for time series with 30 values as was the case for each simulation. For all cases, the $t$ value is larger than 1.67, which indicates that the temperature anomalies obtained
TABLE 3. Student t-tests values.

\begin{tabular}{cccccc}
\hline \hline Experiment & $\mathrm{P}-\mathrm{C}$ & $\mathrm{PV}-\mathrm{C}$ & $\mathrm{R}-\mathrm{C}$ & $\mathrm{RP}-\mathrm{C}$ & $\mathrm{RPV}-\mathrm{C}$ \\
\hline$t$ value & 3.94 & 8.27 & 18.54 & 20.51 & 22.8 \\
\hline
\end{tabular}

for each simulation cannot be attributed to random variability. We also tested the statistical significance of the temperature changes due to the physiological impact over and above the radiative effect (RPV vs R). Student's t-tests were applied to the annual-mean air temperature series averaged over the tropical band $\left(14.4^{\circ} \mathrm{N}-\right.$ $\left.14.4^{\circ} \mathrm{S}\right)$ and the middle high-latitude band $\left(43.2^{\circ}-72^{\circ} \mathrm{N}\right)$ for the last $10 \mathrm{yr}$ of each experiment. For the number of degrees of freedom, $(f=18)$, the calculations RPV versus $\mathrm{R}$ in the Tropics and middle to high latitudes yielded $t$ values of 3.7 and 6.4 , respectively, whereas the limiting value at $95 \%$ confidence level is 2.10 .

\section{Comparison to other studies}

Some recently published simulations of climate response to radiative and physiological forcing have also used advanced land surface models [Pollard and Thompson 1995 (PT95); Thompson and Pollard 1995 (TP95); Henderson-Sellers et al. 1995 (HS95)]. These models treat stomatal conductance empirically and do not include photosynthesis. Vegetation attributes used in these models were specified from datasets derived from the extrapolation of a few ground-based point measurements to global land surfaces (e.g., Dorman and Sellers 1989) in contrast to satellite-based global observations used here. TP95 reported on the impact on climate of doubling atmospheric $\mathrm{CO}_{2}$ alone, whereas HS95 and PT95 considered the sensitivity of simulated climate to a prescribed global reduction $(50 \%)$ in the stomatal conductance, which may be compared with the reductions of between 25\% ( $\mathrm{P}$ and RP cases) and 35\% (PV and RPV cases) calculated in our study. HS95 also included combinatorial consideration of radiative forcing so that their treatments were somewhat analogous to our C, PV, $\mathrm{R}$, and RPV experiments. All these simulations were, however, integrated for periods much shorter than ours, which may explain some of the differences between these studies and results presented here.

Our results for the effect of physiological forcing only (PV) generally lie between those of PT95 and HS95. Over land HS95 found that a 50\% reduction in stomatal conductance alone resulted in an increase of $0.4 \mathrm{~K}$ in annual mean temperature. Changes were larger in July when the Northern Hemisphere vegetation is most active $(0.8 \mathrm{~K})$. Here we observed that a mean reduction in conductance of $35 \%(\mathrm{PV})$ caused somewhat larger increases of $0.7 \mathrm{~K}$ in the annual mean temperature and about $1 \mathrm{~K}$ in July (Fig. 12). PT95 did not report land mean values, but did report changes during the growing season. Their results were generally larger than those obtained in this study. For example, they obtained a 4- 
$\mathrm{K}$ increase in temperature associated with a $20 \mathrm{~W} \mathrm{~m} \mathrm{~m}^{-2}$ decrease in evapotranspiration in the tropical forest as compared to our results of $1 \mathrm{~K}$ and $8 \mathrm{~W} \mathrm{~m}^{-2}$ (Fig. 9). They also show a $2-\mathrm{K}$ temperature increase and $7 \mathrm{~W}$ $\mathrm{m}^{-2}$ decrease in evapotranspiration for boreal forest, which may be compared to $1.5 \mathrm{~K}$ and $5 \mathrm{~W} \mathrm{~m}^{-2}$ obtained here for the same region (see Fig. 11). HS95 found greater differences in warming and evapotranspiration in boreal than in tropical forest regions. Increases in global annual-mean temperature and precipitation caused by radiative forcing varied somewhat between TP95 (2.1 K, 3.3\%), HS95 (2.7 K, 7.73\%), and results reported here $(1.9 \mathrm{~K}, 4.2 \%)$. In contrast to our results, the HS95 simulations showed that the addition of radiative forcing to physiological forcing during the growing season cause much greater warming in boreal than in tropical forest regions. This difference may arise because their model distributes convective precipitation evenly over land grid squares, resulting in an overestimation of canopy interception loss.

Other GCM studies have shown that large-scale changes in the land surface can interact with the atmosphere causing climate to change. As in the deforestation scenarios (e.g., Charney 1975; Nobre et al. 1991; Bonan et al. 1992), our physiologically based senarios involved altering a climatologically important property of vegetation, the stomatal conductance. The 2.7-K increase in temperature for tropical forests indicated in our study (RPV) is on the same order of magnitude as that simulated by GCMs for a complete deforestation of Amazonia (e.g., Nobre et al. 1991). The atmospheric $\mathrm{CO}_{2}$, however, is more likely to double before the Amazon forest is completely gone. A comparison of changes in global assimilation and surface air temperature resulting from the different modeling assumptions shows the importance of the radiative and the physiological forcing and their interactions (Fig. 15). The vectors (R) and (PV), corresponding to cases $R$ and $\mathrm{PV}$, show the separate effects of radiation and physiology, respectively. Although relatively small, the effect of radiation acts in opposite directions in the Tropics and the northern latitudes. While the radiative forcing appears to stimulate the carbon assimilation rate in the Tropics, its impact on the boreal vegetation resulted in a slight inhibition. The total response to $2 \times \mathrm{CO}_{2}$ should lie somewhere along the RP and RPV axes for all cases. The RP and RPV results (Fig. 15) can be compared with the sum of vectors representing the results of separate $\mathrm{R}, \mathrm{RP}$, and $\mathrm{V}$ treatments. We have constructed analogs to the RP and $\mathbf{R P V}$ vectors using $(\mathbf{R}+\mathbf{P})$ and $(\mathbf{R}+\mathbf{P V})$ vectors, respectively. A comparison of $\mathbf{R P}$ with $(\mathbf{R}+\mathbf{P})$, and $\mathbf{R P V}$ with $(\mathbf{R}+\mathbf{P V})$ indicates that the interactions between the radiative and physiological effects can be nonadditive, depending on the geographic location; that is the two vectors cannot always be treated independently because of the climate-vegetation feedback and nonlocal influences, particularly in the northern middle and high latitudes (Fig. 15b). In the Tropics,
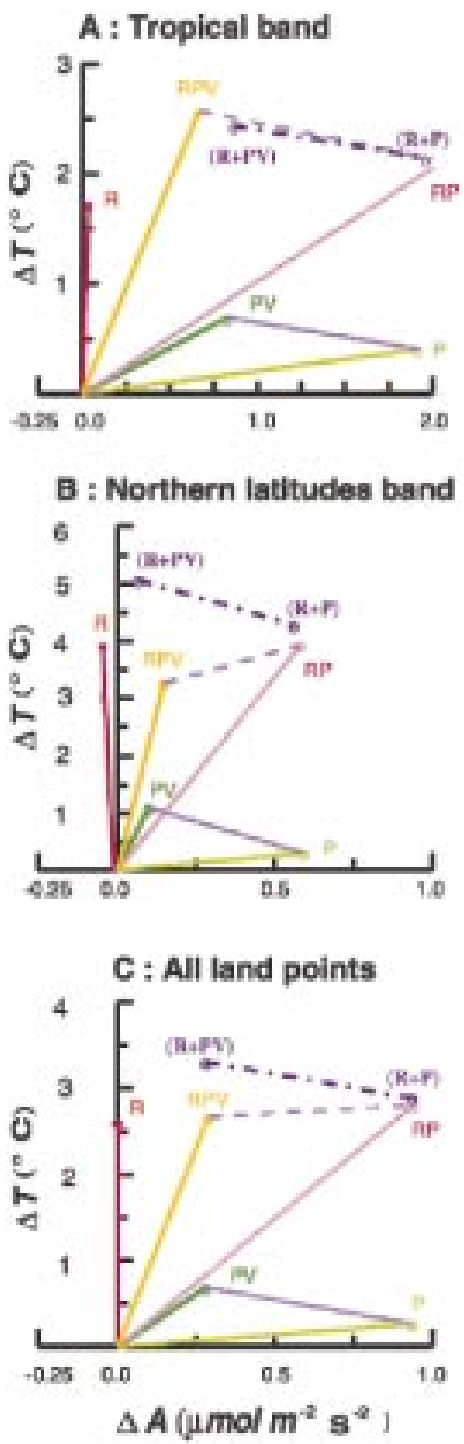

FIG. 15. Mean changes (last $10 \mathrm{yr}$ of runs) in canopy net assimilation plotted against changes in surface temperatures for all experiments for (a) tropical latitude band $\left(14.4^{\circ} \mathrm{S}-14.4^{\circ} \mathrm{N}\right)$; (b) northern latitude band $\left(50.4^{\circ}-70^{\circ} \mathrm{N}\right)$; and (c) all land points. The dotted line joining the "constructed" vectors $(\mathbf{R}+\mathbf{P})$ and $(\mathbf{R}+\mathbf{P V})$ is the analog of the vector (RPV-RP).

however, the results suggest that these effects are approximately additive, presumably because local processes dominate there. It is projected that the value of the assimilation rate for the tropical terrestrial biosphere is inversely related to changes in temperature under 2 $\times \mathrm{CO}_{2}$ conditions (see the RPV-RP axis in Fig. 15a). For the northern latitudes, this is true for the growing season (not shown); however, because of the lower winter temperatures associated with the RPV case, the mean annual assimilation and temperature values appear to be correlated (Fig. 15b). For the globe, the net result is that total assimilation varies widely for little variation in the global mean temperature. The response of assim- 


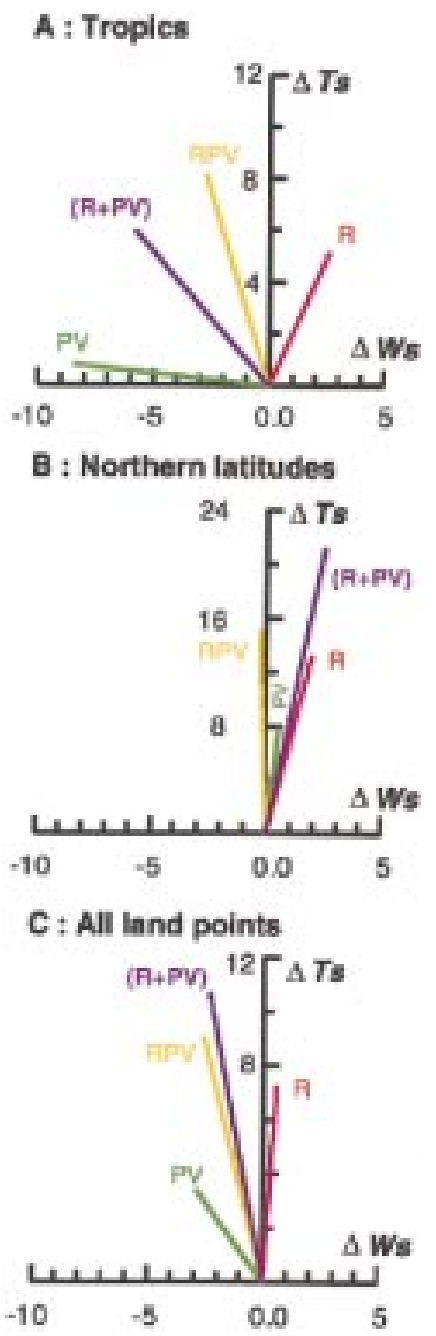

FIG. 16. Mean changes (last $10 \mathrm{yr}$ of runs) in water stress (dimensionless) plotted against changes in high-temperature stress (dimensionless) during the month of July. Both temperature and water stresses are multiplied by 100 for (a) tropical latitude band $\left(14.4^{\circ} \mathrm{S}-\right.$ $\left.14.4^{\circ} \mathrm{N}\right)(\mathrm{Ts}=0.13, \mathrm{Ws}=0.29),(\mathrm{b})$ northern latitude band $\left(50.4^{\circ}\right.$ $\left.70^{\circ} \mathrm{N}\right)(\mathrm{Ts}=0.26, \mathrm{Ws}=0.05)$, and $(\mathrm{c})$ all land points $(\mathrm{Ts}=0.29$, $\mathrm{Ws}=0.19)$. Values in parentheses represent the control means for high-temperature stress and water stress, respectively.

ilation to temperature reflects the climate-vegetation interactions as shown in the water and high-temperature stress factors (Fig. 16). In fact, during the growing season the water stress resulting from the radiative forcing alone is about the same in the Tropics and the northern latitudes (Figs. 16a,b), whereas the high-temperature stress is about three times more in the northern latitudes. On the other hand, the down regulation of the physiology (PV) strongly reduced the water stress in the Tropics with no temperature stress and in the northern latitudes it resulted in high-temperature stress that is about half that of the $\mathrm{R}$ case with no significant variation in the water stress. This suggests that tropical vegetation is more sensitive to soil water than temperature, and the northern latitudes vegetation appears mostly controlled by temperature. When the physiological and radiative effects are combined (RPV), the reduction of the stomatal conductance largely compensated for the water stress created by the radiative forcing but at the same time it limited the transpiration rate and resulted in more heating. This led to an increased high-temperature stress over and above that resulting from the $\mathrm{R}$ case. In the northern latitudes, this combination resulted mainly in increasing the high-temperature stress since there was little water stress. If the responses of assimilation and temperature resulting from these two experiments were linearly added, they would have led to less heating in the Tropics (see RPV and $\mathbf{R}+\mathbf{P V}$ vectors) and more heating in the northern latitudes.

This result is relevant to field studies where vegetation canopies are exposed to enriched $\mathrm{CO}_{2}$. Our results imply that these studies, which generally focus on the carbon budget, should also include energy budget (radiation, water, and heat fluxes) measurements. It will be necessary to combine the results from these studies with anticipated changes in the energy and water balances from GCM investigations in order for a complete picture of the total response to increased $\mathrm{CO}_{2}$ to emerge.

\section{Concluding remarks}

The continuous increase of the atmospheric $\mathrm{CO}_{2}$ concentration and its impact on the earth's climate has attracted the attention of scientists and policy makers. Several modeling studies have assessed global climate responses to an increase in the concentration of atmospheric $\mathrm{CO}_{2}$, but only a few have addressed the interaction between $\mathrm{CO}_{2}$, vegetation, and climate. Deforestation studies have suggested that significant climate feedback could result from the perturbation of the terrestrial vegetation characteristics.

In this study, the potential for an additional warming over the continental land, resulting from the vegetation's physiological response to an increase in atmospheric $\mathrm{CO}_{2}$ concentration, has been investigated using a coupled climate-biosphere model. Five perturbation experiments, designed to assess the radiative and physiological effects of doubled $\mathrm{CO}_{2}$ on climate were compared to a control after equilibrium runs of $30 \mathrm{yr}$ each. The physiological component of our study consisted of altering the capacity of the vegetation to take up $\mathrm{CO}_{2}$ through photosynthesis and lose water through transpiration. These perturbations were combined with the radiative forcing to obtain a complete picture of the radiative and physiological responses to an equilibrium atmospheric $\mathrm{CO}_{2}$ increase. Although many studies have attempted to simulate the $2 \times \mathrm{CO}_{2}$ climate, the results presented here are the first from a global climate model that includes a stomatal conductance-photosynthesis model that responds directly to atmospheric $\mathrm{CO}_{2}$ concentration, and also has its vegetation distribution and vigor defined from satellite observations.

When the $\mathrm{CO}_{2}$ concentration was doubled for the 
physiology alone, photosynthesis increased by about $35 \%$. The mean canopy conductance decreased by about $25 \%$ and gave a decrease in evapotranspiration and precipitation over land. The mean temperature increase was rather small $(+0.3 \mathrm{~K})$. The imposition of down regulation of photosynthesis caused a 35\% decrease in stomatal conductance and a $0.7-\mathrm{K}$ increase in land surface temperature. In general similar physiological responses were observed when the radiative forcing was included.

Changes induced by radiative forcing alone revealed important interactions between climate and vegetation. Although the global mean photosynthesis was not affected by the radiative forcing, a slight stimulation was observed in the tropical regions, whereas in northern latitudes photosynthesis and canopy conductance decreased because of increased high-temperature stress in summer. This was associated with a temperature increase of more than $2 \mathrm{~K}$ greater in the northern latitudes band than in the tropical band (see Table 2). The implications are twofold: on the one hand our results suggest that rapid changes in climate can cause vegetation to be stressed, and that this can feed back on climate. On the other hand, high levels of temperature stress during the growing season indicate that the vegetation is not in equilibrium with the simulated climate. In the real world, vegetation is expected to adjust to temperature increases either through acclimation or species change (Berry and Bjorkman 1980). Furthermore, for nonstressed vegetation, the temperature increase due to radiative forcing alone was substantially smaller during the day when the vegetation is active, than during the night. This indicates that the vegetation can modulate the diurnal temperature cycle in a greenhouse environment and may play a role in the determination of regional climates. Combining the radiative and physiological forcing sometimes produced results that were not predicted from simulations involving the forcings separately. This result was most evident in the strongly seasonal climates in the Northern Hemisphere. During the growing season in this region, the combined forcings tended to produce less heating than the sum of the separate forcings. This trend was even stronger in winter when the Northern Hemisphere physiology is not active. During the Northern Hemisphere winter the combination of radiative and down-regulated physiological forcing caused surface temperatures to be cooler in that region than radiative forcing alone. This result implies that nonlocal effects associated with strong year-round physiological responses in the Tropics can affect highlatitude climate.

Acknowledgments. This work was funded by a NASA Earth Observing System-Interdisciplinary Science Grant, "Biosphere Atmosphere Interactions," D. A. Randal, and by NASA Grant NAG5-3172.

\section{REFERENCES}

Arakawa, A., and V. R. Lamb, 1977: Computational design of the basic dynamical processes of the UCLA general circulation mod- el. Methods in Computational Physics, Vol. 17, Academic Press, 173-265.

$\longrightarrow$, and - 1981: A potential enstrophy and energy conserving scheme for the shallow water equations. Mon. Wea. Rev., 109, $18-36$.

Beerling, D. J., and F. I. Woodward, 1996: Palaeo-ecophysiological perspectives on plant responses to global change. Tree, 11, 2023.

Berry, J. A., and O. Bjorkman, 1980: Photosynthetic response and adaptation to temperature in higher plants. Annu. Rev. Plant Physiol., 31, 491-543.

Boden, T. A., D. P. Kaiser, R. J. Sepanski, and F. W. Stoss, Eds., 1994: A compendium of data on global change. Trends '93, Oak Ridge National Laboratory, 984 pp.

Bonan, G. B., D. Pollard, and S. L. Thompson, 1992: Effects of boreal forest vegetation on global climate. Nature, 359, 716-718.

Bryan, K., and M. J. Spelman, 1985: The ocean's response to a carbon dioxide-induced warming. J. Geophys. Res., 90 (C6), 11 67911688.

Charney, J. G., 1975: Dynamics of deserts and drought in the Sahel. Quart. J. Roy. Meteor. Soc., 101, 193-202.

Ciais, P., P. P. Tans, M. Trolier, J. W. C. White, and R. J. Francey, 1995a: A large Northern Hemisphere terrestrial $\mathrm{CO}_{2}$ sink indicated by $13 \mathrm{C} / 12 \mathrm{C}$ of atmospheric $\mathrm{CO}_{2}$. Science, 269, 10981102.

— of $\mathrm{CO}_{2}$ as inferred by delta $13 \mathrm{C}$ measurements from the NOAA/ CMDL Global Air Sampling Network. J. Geophys. Res., 100, 5051-5070.

Collatz, G. J., J. T. Ball, C. Grivet, and J. A. Berry, 1991: Physiological and environmental regulation of stomatal conductance, photosynthesis and transpiration: A model that includes a laminar boundary layer. Agric. For. Meteor., 54, 107-36.

_- M. Ribas-Carbo, and J. A. Berry, 1992: Coupled photosynthesis-stomatal conductance model for leaves of C4 plants. Aust. J. Plant Physiol., 19, 519-538.

Cowan, I. R., 1977: Stomatal behavior and environment. Adv. Bot. Res., 4, 117-228.

, and G. D. Farquhar, 1977: Stomatal function in relation to leaf metabolism and environment. Symp. Soc. Exp. Biol., 31, 471505.

Denning, A. S., I. Fung, and D. A. Randall, 1995: Simulation of the atmospheric transport of carbon dioxide with a general circulation model. Nature, 376, 240-243.

—, G. J. Collatz, C. Zhang, D. A. Randall, J. A. Berry, P. J. Sellers, G. D. Colello, and D. A. Dazlich, 1996a: Simulations of terrestrial carbon metabolism and atmospheric $\mathrm{CO}_{2}$ in a general circulation model. Part I: Surface carbon fluxes. Tellus, 48B, 521542.

- D. A. Randall, G. J. Collatz, and P. J. Sellers, 1996b: Simulations of terrestrial carbon metabolism and atmospheric $\mathrm{CO}_{2}$ in a general circulation model. Part II: Simulated $\mathrm{CO}_{2}$ concentrations. Tellus, 48B, 543-567.

Dorman, J. L., and P. J. Sellers, 1989: A global climatology of albedo, roughness length and stomatal resistance for atmospheric general circulation models as represented by the simple biosphere model (SiB). J. Appl. Meteor., 28, 833-855.

Field, C. B., 1991: Ecological scaling of carbon gain to stress and resource availability. Integrated Responses of Plants to Stress, H. A. Mooney, W. E. Winner, and E. J. Pell, Eds., Academic Press, 35-65.

—, F. S. Chapin III, P. A. Matson, and H. A. Mooney, 1992: Responses of terrestrial ecosystems to the changing atmosphere: A resource-based approach. Annu. Rev. Ecol. Syst., 23, 201-235.

- R. B. Jackson, and H. A. Mooney, 1995: Stomatal responses to increased $\mathrm{CO}_{2}$ : Implications from the plant to the global scale. Plant, Cell Environ., 18, 1214-1225.

Fowler, L. D., and D. A. Randall, 1996a: Liquid and ice cloud microphysics in the CSU general circulation model. Part II: Impact 
on cloudiness, the earth's radiation budget, and the general circulation of the atmosphere. J. Climate, 9, 530-560.

, and - 1996b: Liquid and ice cloud microphysics in the CSU general circulation model. Part III: Sensitivity to modeling assumptions. J. Climate, 9, 561-586.

— - — , and S. A. Rutledge, 1996: Liquid and ice cloud microphysics in the CSU general circulation model. Part I: Model description and simulated microphysical processes. J. Climate, 9, 489-529.

Gunderson, C. A., and S. D. Wullschleger, 1994: Photosynthetic acclimation in trees to rising atmospheric $\mathrm{CO}_{2}: \mathrm{A}$ broader perspective. Photosyn. Res., 39, 369-388.

Hansen, J., A. Lacis, D. Rind, and G. Russell, 1984: Climate sensitivity: Analysis of feedback mechanisms. Climate Processes and Climate Sensitivity, Geophys. Monogr., No. 29, Amer. Geophys. Union, 130-163.

—, I. Fung, A. Lacis, D. Rind, S. Lebedeff, R. Ruedy, and G. Russell, 1988: Global climate changes as forecast by Goddard Institute for Space Studies Three-dimensional Model. J. Geophys. Res., 93, 9341-9364.

Harshvardhan, R., D. A. Randall, and T. G. Corsetti, 1987: A fast radiation parameterization for general circulation models. $J$. Geophys. Res., 92, 1009-1016.

Henderson-Sellers, A., K. McGuffie, and C. Gross, 1995: Sensitivity of global climate model simulations to increased stomatal resistance and $\mathrm{CO}_{2}$ increases. J. Climate, 8, 1738-1756.

Houghton, J. T., G. J. Jenkins, and J. J. Ephraums, Eds., 1990: The IPCC Scientific Assessment. Cambridge University Press, 364 pp.

, L. G. Meira Filho, B. A. Callender, N. Harris, A. Kattenberg, and K. Maskell, Eds., 1996: The science of climate change. Contribution of working group 1 to the second assessment report of the intergovernmental panel on climate change. Climate Change 1995, Cambridge University Press, $56 \mathrm{pp}$.

Jensen, T. G., D. A. Dazlich, and D. A. Randall, 1995: A one-dimensional mixed layer ocean and sea ice model with prescribed oceanic heat transport. Dept. of Atmospheric Science, Colorado State University, Paper No. 593, 48 pp. [Available from Dept. of Atmospheric Science, Colorado State University, Fort Collins, CO 80523.]

Karl, T. R., and Coauthors, 1993: Asymmetric trends of daily maximum and minimum temperature. Bull. Amer. Meteor. Soc., 74, $1007-1023$.

Morison, J. I. L., 1987: Intercellular $\mathrm{CO}_{2}$ concentration and stomatal response to $\mathrm{CO}_{2}$. Stomatal Function, E. Zeiger, G. D. Farquhar, and I. R. Cowan, Eds., Stanford University Press, 229-252.

Murphy, J. M., 1995: Transient response of the Hadley Centre Coupled Model to increasing carbon dioxide. Part I: Control climate and flux adjustment. J. Climate, 8, 36-56.

- and J. F. B. Mitchell, 1995: Transient response of the Hadley Centre Coupled Model to increasing carbon dioxide. Part II:
Spatial and temporal structure of response. J. Climate, 8, 5780

Nobre, C. A., P. J. Sellers, and J. Shukla, 1991: Amazonian deforestation and regional climate change. J. Climate, 4, 957-987.

Penuelas, J., and R. Matamala, 1990: Changes in nitrogen and sulfur leaf content, stomatal density and specific leaf area of 14 plant species during the last three centuries of carbon dioxide increase. J. Exp. Botany, 41, 1119-1124.

Pollard, D., and S. L. Thompson, 1995: Use of a land-surface-transfer scheme (LSX) in a global climate model: The response to doubling stomatal resistance. Global Planet. Change, 286, 1-32.

Randall, D. A., and D. M. Pan, 1993: Implementation of the ArakawaSchubert cumulus parameterization with a prognostic closure. Representation of Cumulus Convection in Numerical Models of the Atmosphere, Meteor. Monogr., No. 46, Amer. Meteor. Soc., $137-144$.

— (SiB2) for GCMs. Part III: The greening of the Colorado State University General Circulation Model. J. Climate, 9, 738-763.

Sellers, P. J., J. A. Berry, G. J. Collatz, C. B. Field, and F. G. Hall, 1992: Canopy reflectance, photosynthesis and transpiration. Part III: A re-analysis using improved leaf models and a new canopy integration scheme. Remote Sens. Environ., 42, 187-216.

— logical effects of doubled atmospheric $\mathrm{CO}_{2}$ on climate. Science, 271, 1402-1406.

— D. A. Randall, G. J. Collatz, J. A. Berry, C. B. Field, D. A. Dazlich, C. Zhang, and L. Bounoua, 1996b: A revised land surface parameterization (SiB2) for atmospheric GCMs. Part I: Model formulation. J. Climate, 9, 676-705.

- S. O. Los, C. J. Tucker, C. O. Justice, D. A. Dazlich, G. J. Collatz, and D. A. Randall, 1996c: A revised land surface parameterization ( $\mathrm{SiB} 2$ ) for atmospheric GCMs. Part II: The generation of global fields of terrestrial biophysical parameters from satellite data. J. Climate, 9, 706-737.

Stouffer, R. J., S. Manabe, and K. Bryan, 1989: Interhemispheric asymmetry in climate response to a gradual increase of atmospheric $\mathrm{CO}_{2}$. Nature, 342, 660-662.

Suarez, M. J., A. Arakawa, and D. A. Randall, 1983: Parameterization of the planetary boundary layer in the UCLA general circulation model: Formulation and results. Mon. Wea. Rev., 111, 22242243.

Tissue, D. T., R. B. Thomas, and B. R. Strain, 1993: Long-term effects of elevated $\mathrm{CO}_{2}$ and nutrients on photosynthesis and Rubisco in loblolly pine seedlings. Plant, Cell Environ., 16, 859-865.

Thompson, S. L., and D. Pollard, 1995: A global climate model (GENESIS) with a land-surface-transfer scheme (LSX). Part II: $\mathrm{CO}_{2}$ sensitivity. J. Climate, 8, 1104-1121.

Washington, W. M., and G. A. Meehl, 1989: Climate sensitivity due to increased $\mathrm{CO}_{2}$ : Experiments with a coupled atmosphere and ocean general circulation model. Climate Dyn., 4, 1-48.

Woodward, F. I., 1987: Stomatal numbers are sensitive to increases in $\mathrm{CO}_{2}$ from pre-industrial levels. Nature, 327, 617-618. 